\title{
Characterization of Dissolved Solids in Water Resources of Agricultural Lands near Manila, Utah, 2004-05
}

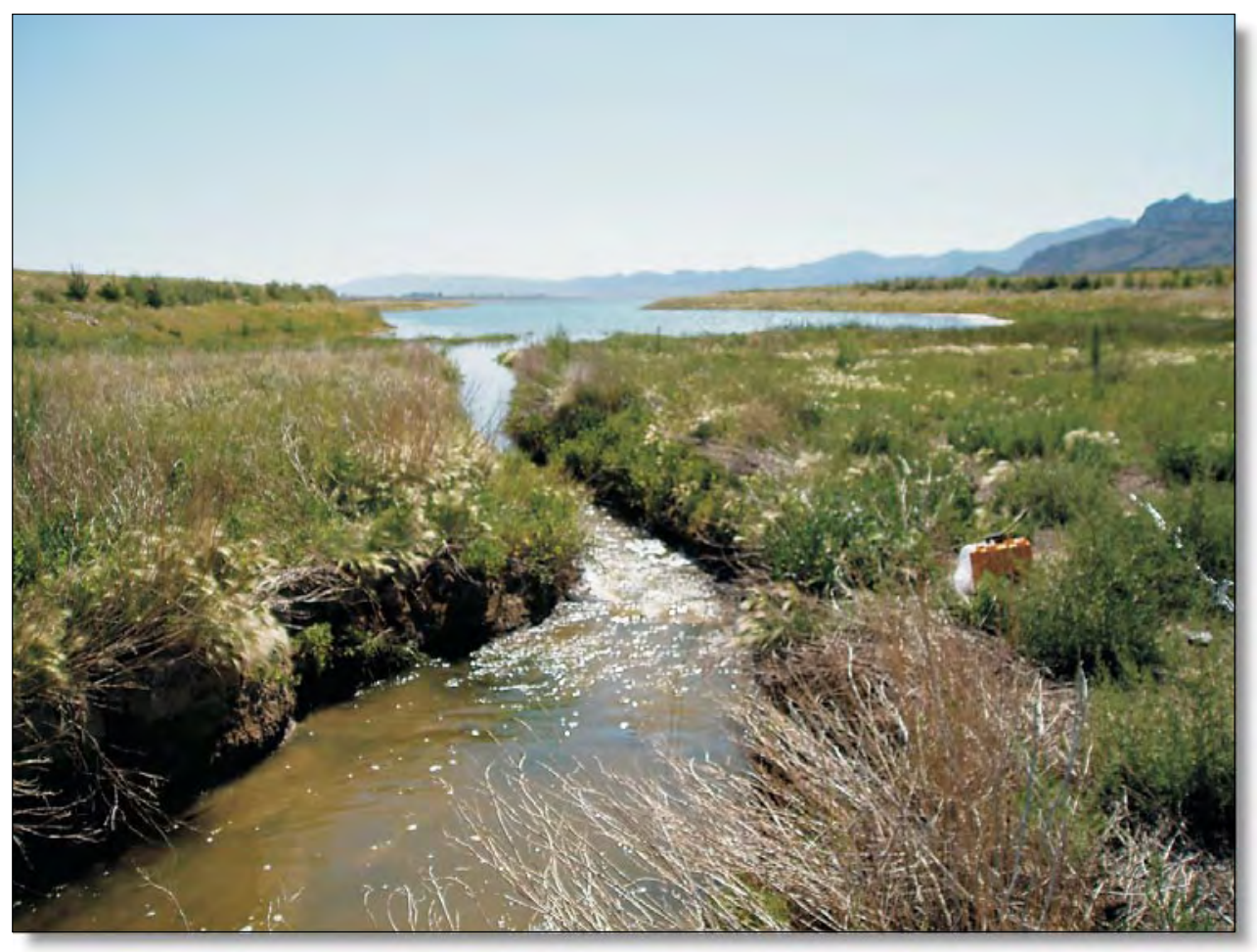

\section{Scientific Investigations Report 2006-5211}

Version 2.0, June 2007 
Cover photo: Birch Spring Draw outflow to Flaming Gorge Reservoir near Manila, Utah. (Photograph by Steven Gerner.) 


\section{Characterization of Dissolved Solids in Water Resources of Agricultural Lands near Manila, Utah, 2004-05}

By S.J. Gerner, L.E. Spangler, B.A. Kimball, and D.L. Naftz

Scientific Investigations Report 2006-5211

Version 2.0, June 2007

Prepared in cooperation with the

NATURAL RESOURCES CONSERVATION SERVICE

U.S. Department of the Interior

U.S. Geological Survey 


\section{U.S. Department of the Interior \\ Dirk Kempthorne, Secretary}

\section{U.S. Geological Survey \\ Mark D. Myers, Director}

Reston, Virginia: 2006

For additional information write to:

U.S. Geological Survey

Director, USGS Utah Water Science Center

2329 W. Orton Circle

Salt Lake City, UT 84119-2047

Email: GS-W-UTpublic-info@usgs.gov

URL: http://ut.water.usgs.gov/

For more information about the USGS and its products:

Telephone: 1-888-ASK-USGS

World Wide Web: http://www.usgs.gov/

Any use of trade, firm, or product names is for descriptive purposes only and does not imply endorsement by the U.S. Government.

Although this report is in the public domain, permission must be secured from the individual copyright owners to reproduce any copyrighted materials contained within this report. 


\section{Contents}

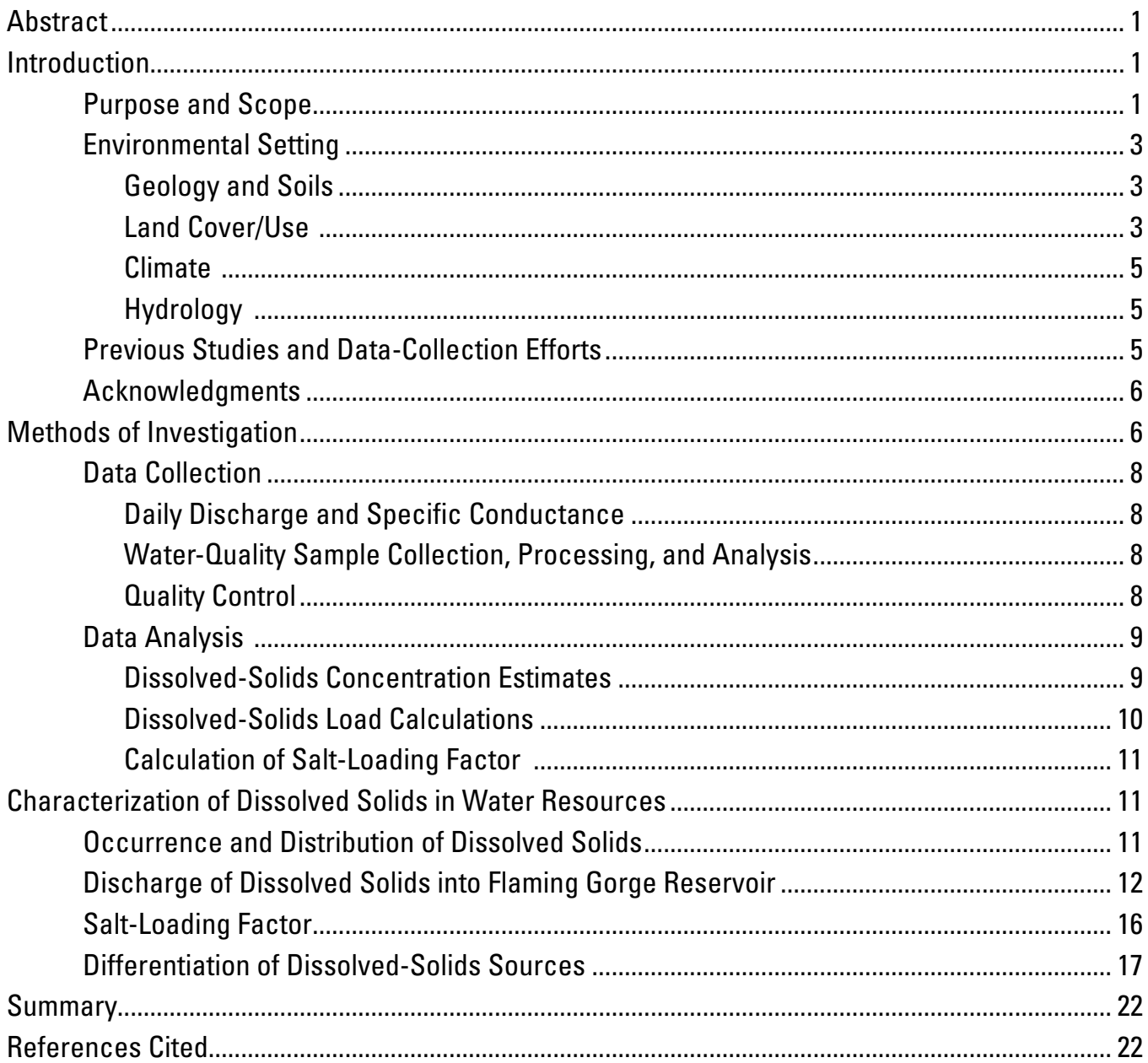

\section{Figures}

Figure 1. Geographic features and water-quality monitoring sites in the study area near

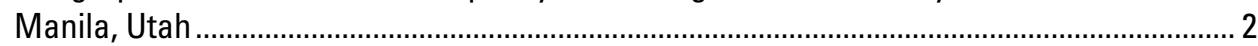

Figure 2. Geology of the study area near Manila, Utah..................................................................... 4

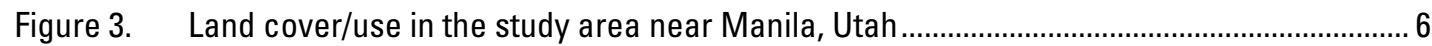

Figure 4. Relation of total adjusted dissolved-solids load at synoptic sites and total dissolvedsolids load at fixed outflow-monitoring sites near Manila, Utah .......................................... 10

Figure 5. Relative composition of water in the study area near Manila, Utah ..................................... 13

Figure 6. Distribution of dissolved-solids concentration and load, and discharge at waterquality monitoring sites near Manila, Utah......................................................................... 14

Figure 7. Estimated daily total adjusted dissolved-solids load discharged from the study area near Manila, Utah, July 1, 2004, through June 30, 2005 16

Figure 8. Cumulative total adjusted dissolved-solids load discharged from the study area near Manila, Utah, July 1, 2004, through June 30, 2005 
Figure 9. Variation of $\delta^{87} \mathrm{Sr}$ with strontium concentration in samples collected from selected sites near Manila, Utah.

Figure 10. Variation of $\delta^{11} \mathrm{~B}$ with boron concentration in samples collected from selected sites

near Manila, Utah.

\section{Tables}

Table 1. Site characteristics and summary of dissolved-solids concentration and load for water-quality monitoring sites near Manila, Utah.

Table 2. Instantaneous discharge and properties of water samples collected from waterquality monitoring sites near Manila, Utah.....

Table 3. Concentration of major ions in water samples collected from water-quality monitoring sites near Manila, Utah.

Table 4. Field and analytical methods and minimum reporting levels for water-quality field measurements and constituent concentrations in samples collected from waterquality monitoring sites near Manila, Utah

Table 5. Relative percentage of major ions in selected water samples collected at waterquality monitoring sites near Manila, Utah

Table 6. Estimated dissolved-solids load in Sheep Creek Canal and Peoples Canal near Manila, Utah, April-October 2004

Table 7. Dissolved-solids load at inflow, outflow, and fixed outflow-monitoring sites in the study area near Manila, Utah

Table 8. Precipitation at Manila, Utah, and streamflow in Henrys Fork near Manila, Utah, July 2004 through June 2005

Table 9. Discharge and water-quality characteristics for selected water-quality monitoring sites used in the calculation of salt-loading factors for the study area near Manila, Utah

Table 10. Site identification and characteristics, chemical concentration, isotope ratio, and specific conductance of samples collected from selected water-quality monitoring sites near Manila, Utah 


\section{Conversion Factors, Datums, and Abbreviated Water-Quality Units}

\begin{tabular}{lll}
\hline \multicolumn{1}{c}{ Multiply } & By & To obtain \\
\hline foot (ft) & Length & \\
mile (mi) & 0.3048 & meter $(\mathrm{m})$ \\
inch (in.) & 1.609 & kilometer $(\mathrm{km})$ \\
& 2.54 & centimeter $(\mathrm{cm})$ \\
\hline acre & Area & \\
acre & 0.4047 & hectare $(\mathrm{ha})$ \\
square mile (mi $\left.{ }^{2}\right)$ & 0.004047 & square kilometer $\left(\mathrm{km}^{2}\right)$ \\
& 2.590 & square kilometer $\left(\mathrm{km}^{2}\right)$ \\
\hline acre-foot (acre-ft) & Volume & \\
& 1,233 & cubic meter $\left(\mathrm{m}^{3}\right)$ \\
\hline cubic foot per second (ft $3 / \mathrm{s})$ & Rate & \\
gallon per minute (gal/min) & 0.02832 & cubic meter per second ( $\left.\mathrm{m}^{3} / \mathrm{s}\right)$ \\
inch per year (in/yr) & 3.785 & liter per minute $(\mathrm{L} / \mathrm{m})$ \\
& 2.54 & centimeter per year $(\mathrm{cm} / \mathrm{yr})$ \\
\hline ton per day (ton/d) & Mass & \\
\hline
\end{tabular}

Temperature in degrees Celsius $\left({ }^{\circ} \mathrm{C}\right)$ may be converted to degrees Fahrenheit $\left({ }^{\circ} \mathrm{F}\right)$ as follows:

$$
{ }^{\circ} \mathrm{F}=\left(1.8 \times{ }^{\circ} \mathrm{C}\right)+32 .
$$

Temperature in degrees Fahrenheit $\left({ }^{\circ} \mathrm{F}\right)$ may be converted to degrees Celsius $\left({ }^{\circ} \mathrm{C}\right)$ as follows:

$$
{ }^{\circ} \mathrm{C}=\left({ }^{\circ} \mathrm{F}-32\right) / 1.8 .
$$

Horizontal coordinate information is referenced to the North American Datum of 1983 (NAD 83). Vertical coordinate information is referenced to the National Geodetic Vertical Datum of 1929 (NGVD 29). Altitude, as used in this report, refers to distance above the vertical datum.

Specific conductance is reported in microsiemens per centimeter at 25 degrees Celsius $\left(\mu \mathrm{S} / \mathrm{cm}\right.$ at $\left.25^{\circ} \mathrm{C}\right)$. Concentrations of chemical constituents in water are reported either in milligrams per liter (mg/L), micrograms per liter ( $\mu \mathrm{g} / \mathrm{L})$, or nanograms per liter $(\mathrm{ng} / \mathrm{L})$.

Isotopic ratios are reported in units of permil (per thousand). 


\title{
Characterization of Dissolved Solids in Water Resources of Agricultural Lands near Manila, Utah, 2004-05
}

\author{
By S.J. Gerner, L.E. Spangler, B.A. Kimball, and D.L. Naftz
}

\section{Abstract}

Agricultural lands near Manila, Utah, have been identified as contributing dissolved solids to Flaming Gorge Reservoir. Concentrations of dissolved solids in water resources of agricultural lands near Manila, Utah, ranged from 35 to 7,410 milligrams per liter. The dissolved-solids load in seeps and drains in the study area that discharge to Flaming Gorge Reservoir ranged from less than 0.1 to 113 tons per day. The most substantial source of dissolved solids discharging from the study area to the reservoir was Birch Spring Draw. The mean daily dissolved-solids load near the mouth of Birch Spring Draw was 65 tons per day.

The estimated annual dissolved-solids load imported to the study area by Sheep Creek and Peoples Canals is 1,330 and 13,200 tons, respectively. Daily dissolved-solid loads discharging to the reservoir from the study area, less the amount of dissolved solids imported by canals, for the period July 1 , 2004, to June 30, 2005, ranged from 72 to 241 tons per day with a mean of 110 tons per day. The estimated annual dissolved-solids load discharging to the reservoir from the study area, less the amount of dissolved solids imported by canals, for the same period was 40,200 tons. Of this 40,200 tons of dissolved solids, about 9,000 tons may be from a regional source that is not associated with agricultural activities. The salt-loading factor is 3,670 milligrams per liter or about 5.0 tons of dissolved solids per acre-foot of deep percolation in Lucerne Valley and 1,620 milligrams per liter or 2.2 tons per acre-foot in South Valley.

The variation of $\delta^{87} \mathrm{Sr}$ with strontium concentration indicates some general patterns that help to define a conceptual model of the processes affecting the concentration of strontium and the $\delta^{87} \mathrm{Sr}$ isotopic ratio in area waters. As excess irrigation water percolates through soils derived from Mancos Shale, the $\delta^{87} \mathrm{Sr}$ isotopic ratio ( 0.21 to 0.69 permil) approaches one that is typical of deep percolation from irrigation on Mancos Shale. The boron concentration and $\delta^{11} \mathrm{~B}$ value for the water sample from Antelope Wash, being distinctly different from water samples from other sites, is evidence that water in Antelope Wash may contain a substantial component of regional ground-water flow.

\section{Introduction}

Water from the Colorado River and its tributaries is used for municipal and industrial purposes by about 27 million people and irrigates nearly 4 million acres of land in the Western
United States (U.S. Department of the Interior, 2003). Water users in the Upper Colorado River Basin consume water from the Colorado River and its tributaries, reducing the amount of water in the river suitable for domestic use and crop irrigation. In addition, application of water to agricultural land within the basin in excess of crop needs can increase the transport of dissolved solids to the river. As a result, the dissolved-solids concentration in the Colorado River has increased, affecting downstream water users. In this report, the term "dissolved solids" refers to the sum of the individual dissolved constituents present in water, and it is synonymous with "salinity."

In 1974, Congress enacted the Colorado River Basin Salinity Control Act, which authorizes the construction, operation, and maintenance of salinity control works in the Colorado River Basin. The U.S. Department of Agriculture (USDA) is a partner in the Colorado River Salinity Control Program, directing offices of the Natural Resources Conservation Service (NRCS) in the Upper Colorado River Basin to make reductions, where possible, in the dissolved-solids load discharging to the Colorado River from agricultural lands. The NRCS has been actively working to reduce these dissolvedsolid loads through promotion of improved irrigation methods.

The agricultural lands surrounding Manila, Utah (fig. 1), have been identified by the NRCS as areas contributing dissolved solids to Flaming Gorge Reservoir (FGR). Estimates of the amount of dissolved solids discharged to FGR that are attributable to agricultural lands in the area are needed by resource managers to assess the benefits that may be realized from irrigation system improvements. During 2004-05, the U.S. Geological Survey (USGS) investigated the occurrence and distribution of dissolved solids in water from the agricultural lands near Manila, Utah, to determine the amount of dissolved solids being discharged to FGR.

\section{Purpose and Scope}

This report documents the methods used in, and results of, an investigation to determine the amount of dissolved solids contributed to FGR from Lucerne Valley, South Valley, Antelope Hollow, and a portion of Henrys Fork near Manila, Utah. The report includes a description of the occurrence and distribution of dissolved solids in water resources in or near the agricultural lands near Manila. The report also includes a discussion of the use of isotopes to evaluate the relative contributions of dissolved solids from irrigation and non-irrigation sources.

Measurements of specific conductance and surface-water discharge made at 23 water-quality monitoring sites from 


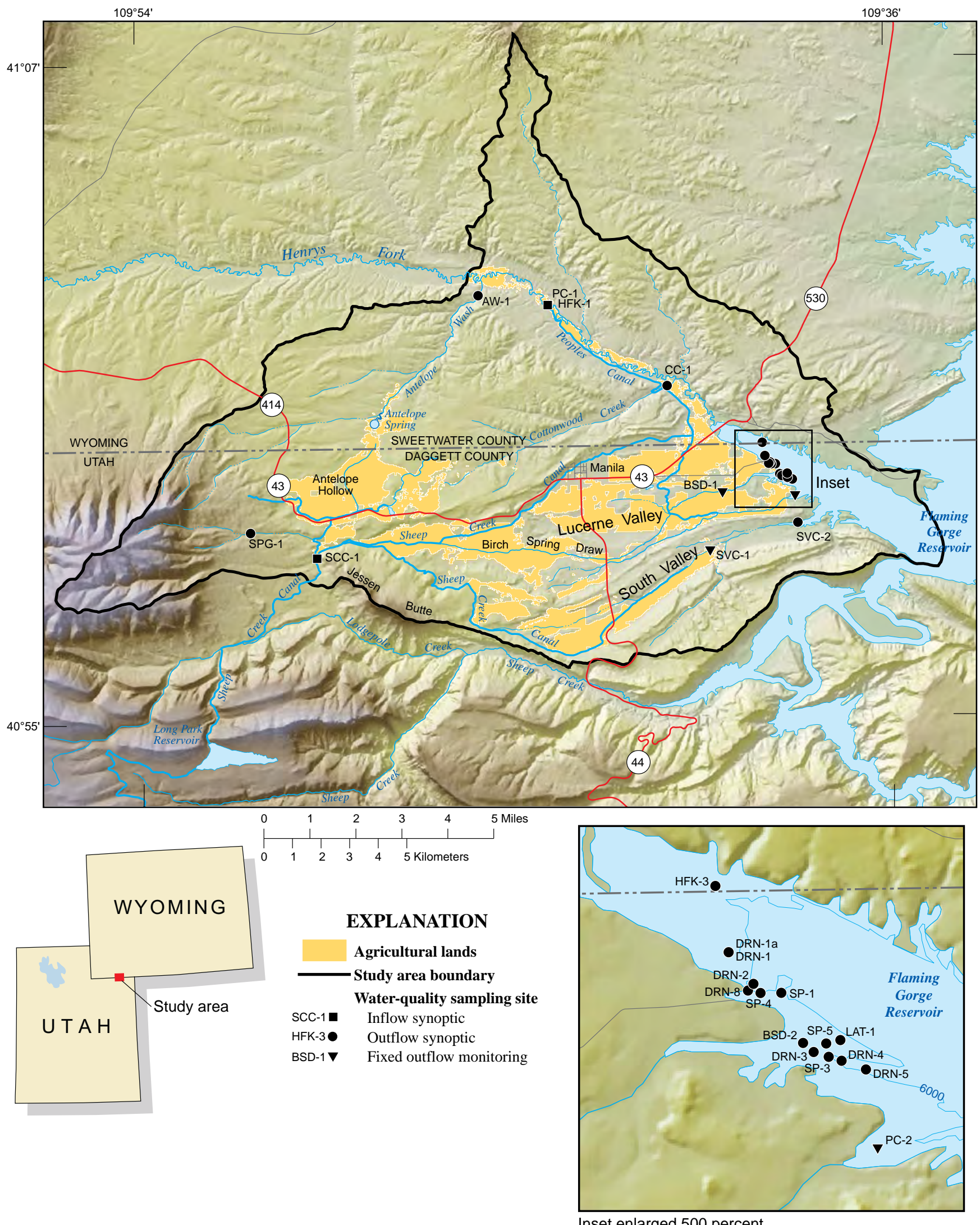

Inset enlarged 500 percent

Figure 1. Geographic features and water-quality monitoring sites in the study area near Manila, Utah. 
May 2004 to June 2005, and results from chemical analysis of water samples collected at those sites, are presented in this report. Estimates of the dissolved-solids load discharging from the study area were determined from these data and also are presented in this report.

\section{Environmental Setting}

The study area is located near the small farming community of Manila, just west of FGR along the border between Utah and Wyoming, and covers about $100 \mathrm{mi}^{2}$. The northern part of the study area is located in Sweetwater County, Wyoming, and the southern part is located in Daggett County, Utah (fig. 1). The study area includes the watersheds of Antelope Hollow, Birch Spring Draw, South Valley, and the lower part of Henrys Fork. Water discharged from these watersheds is impounded in FGR in the eastern part of the study area. The southern border of the study area is defined by a prominent, steeply dipping ridge that includes Jessen Butte. Altitudes range from about $6,000 \mathrm{ft}$ in the eastern part of the study area along FGR, to as much as $8,600 \mathrm{ft}$ on Jessen Butte, in the southwestern part of the area. Vegetation in the study area consists of willows and cottonwoods along the rivers, sagebrush and rabbit brush along the valley bottoms, and evergreen forests at the higher altitudes.

Dispersed settlement in the Manila area began in the mid to late 1800 s with the establishment of small cattle and horse ranches. In the fall of 1890, the agricultural possibilities of Dry Valley (later changed to Lucerne Valley) were recognized by Adolph Jessen, an engineer, who, along with others, incorporated the Lucerne Land and Water Company in 1892. In 1894, construction began on the 14.5-mi-long Sheep Creek Canal to the head of Lucerne Valley. The main canal was rated at $50 \mathrm{ft}^{3} / \mathrm{sec}$ and was divided into two $20 \mathrm{ft}^{3} / \mathrm{sec}$ laterals. One lateral flowed $6 \mathrm{mi}$ along the northern slope of the valley and the other followed the south slope for $3 \mathrm{mi}$. The overall canal system irrigated several thousand acres mostly in the central and western sections of the valley (Johnson and others, 1998). In 1899, the Lucerne Land and Water Company divested itself of the Sheep Creek Canal, and the Sheep Creek Irrigation Company was created and controlled by local irrigators. In response to a need to obtain more economical water, the Peoples Canal Company was formed by a group of homesteaders in 1899 to irrigate 2,000 acres at the eastern end of the valley by diverting water from Henrys Fork. The diversion ditch and Peoples Canal were completed in 1902 and water was delivered the following spring. A century later, water from Henrys Fork and Sheep Creek are still diverted into Lucerne Valley for irrigation (fig. 1).

\section{Geology and Soils}

The geology of the study area consists of a sequence of Jurassic, Cretaceous, and Tertiary-age sedimentary rocks of marine and terrestrial origin that generally dip to the north away from the Uinta Mountains. As a result, the youngest rocks are located in the northern part of the study area. Closer to the mountain front, the dip of the rocks is steeper and ridges of more-resistant sandstone separate intervening valleys of less-resistant rocks such as shales. Jurassic-age sandstones, shales, and mudstones border and underlie most of South Valley (fig. 2). These units include the Navajo Sandstone and the Curtis, Entrada, Carmel, and Morrison Formations. The Cretaceous-age Dakota and Cedar Mountain Formations form the ridges that divide South Valley from Lucerne Valley and consist of interbedded fluvial sandstones, siltstones, and shales.

The Mancos Shale underlies most of Lucerne Valley, including the area around the community of Manila, and consists primarily of silts and clays that tend to form low undulating hills. Streamflow from rainfall and irrigation runoff and from springs and seeps in these areas can have high dissolvedsolids concentrations (Mason and Miller, 2004).

The northern part of the study area is underlain by early Tertiary-age sediments that make up the Wasatch, Green River, and Bridger Formations. These units consist of variable amounts of limestone (marls), shales, sandstones (partly tuffaceous), and mudstones that were deposited in lacustrine (Green River Formation) and fluvial (Wasatch and Bridger Formations) environments. Most of the land in the Wyoming part of the study area is underlain by the Eocene-age Bridger Formation, which weathers into badlands in some areas. Irrigated lands adjacent to the floodplain of Henrys Fork are underlain by the Laney Member of the Green River Formation (Mason and Miller, 2004). Quaternary-age alluvium and colluvial deposits also are present along the floodplain of Henrys Fork as well as along smaller tributary drainages throughout the study area. These deposits consist primarily of sands and gravels that have been transported downstream from the Uinta Mountains.

Soils in the study area are derived from a variety of rock types, including shale, sandstone, and mudstone. Soils in the irrigated areas of Lucerne Valley, which are derived primarily from the Mancos Shale, are mostly classified as Rhoamett silty clays, Poposhia loams, and McFadden fine sandy loams (Schwarz and Alexander, 1995). In parts of Lucerne Valley, particularly those south and east of Manila, salt or alkali flats also develop from near-surface evaporation and concentration of minerals in the shaly soils. In contrast, soils developed from the Green River Formation along Henrys Fork are primarily classified as Luhon channery loams. In the northern part of the area where the Bridger Formation crops out, the soils are classified within the Roto-Rockinchair-Rencot complex and Blazon thin solum-Blazon-Lilsnake complex. Along the floodplain of Henrys Fork, soils derived from the alluvial sediments are part of the Hagga-Cowestglen association.

\section{Land Cover/Use}

Land-cover and -use data were obtained from the National Land Cover Dataset (NLCD) (U.S. Geological 


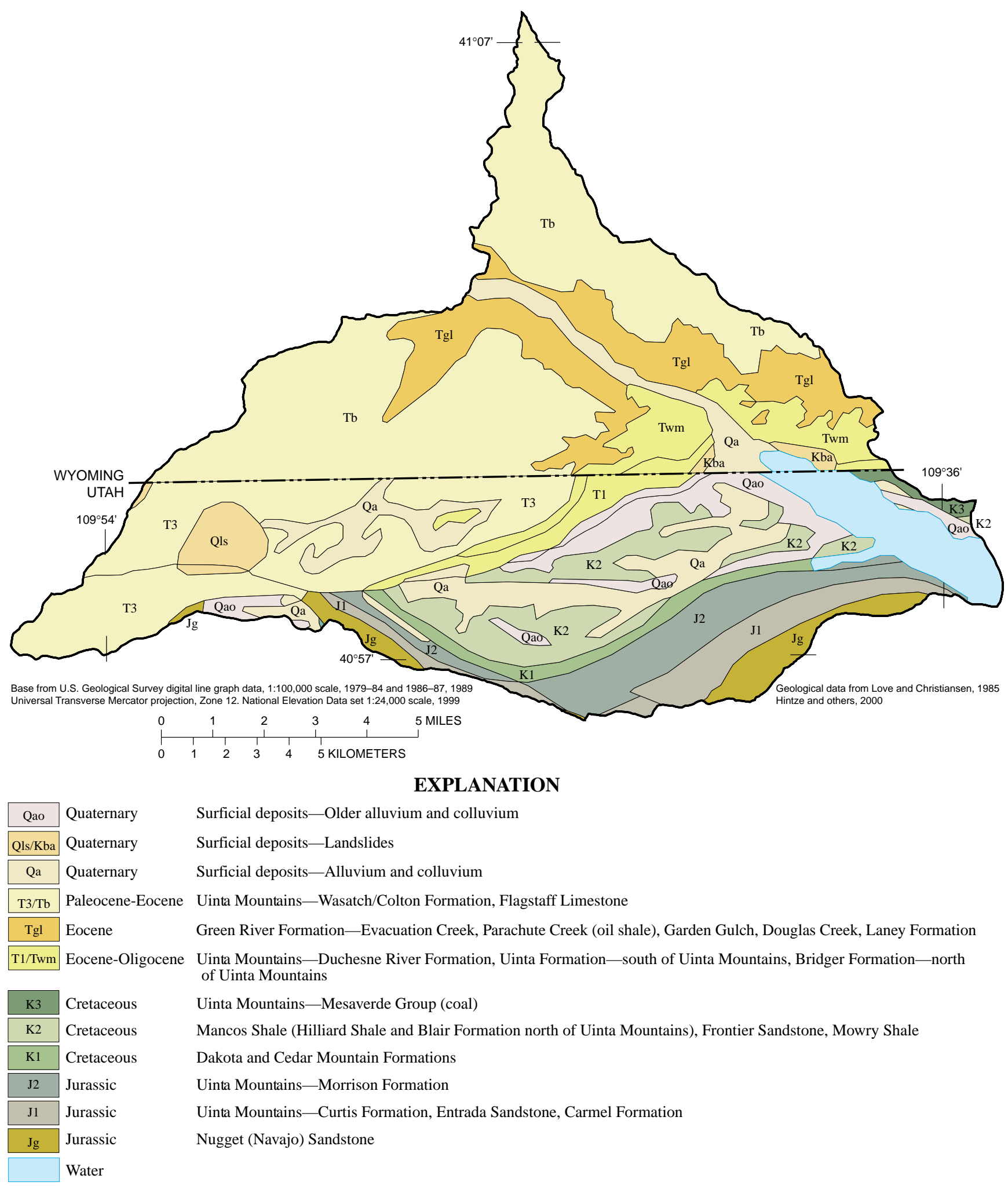

Figure 2. Geology of the study area near Manila, Utah. 
Survey, 2006). This data set provides a consistent land-cover data layer for the conterminous United States and represents conditions in the early to mid-1990s. Land cover in the study area consists primarily of shrublands that are used for grazing; about 41,000 acres of shrublands are distributed across the study area. Agricultural lands in Lucerne Valley, South Valley, Antelope Hollow, and along Henrys Fork amount to about 9,800 acres (fig. 3). Alfalfa and hay are the primary crops with about 7,700 acres of pasture lands and 1,900 acres of alfalfa. Fallow areas, row crops, and small grains occupy less than 100 acres of land, collectively. Forest and grasslands cover about 4,500 and 4,900 acres, respectively. Forests are primarily located at higher altitudes along the southern margin of the area and along ridgelines within Lucerne Valley; however, grasslands are fairly evenly distributed throughout the study area. Urban lands make up about 930 acres in the vicinity of Manila.

\section{Climate}

Climate in the study area consists of mild summers and cold winters. For 1952 through 2005, mean annual temperature was $45.3^{\circ} \mathrm{F}$ (Western Regional Climate Center, 2005). Extremes have ranged from a low of $-33^{\circ} \mathrm{F}$ to a high of $99^{\circ} \mathrm{F}$. Mean annual precipitation in the study area is 9.14 in., with the precipitation distributed through the spring (2.94 in.), summer (2.96 in.), fall (2.24 in.), and winter (1.00 in.). Mean annual snowfall in the study area is about $38 \mathrm{in} / \mathrm{yr}$, with higher quantities on the ridges and mountains along the southern boundary of the area. The pan evaporation rate (May-October) in the study area is about $33 \mathrm{in} / \mathrm{yr}$ (Hemphill, 2005), substantially exceeding precipitation.

\section{Hydrology}

Site characteristics of water-quality monitoring sites are listed in table 1 . Most of the surface water in the study area originates in the Uinta Mountains immediately to the west and southwest, and flows generally west to east through the area to eventually discharge into FGR. Henrys Fork has the most flow of any perennial stream in the study area, originating from streams that flow north from the Uinta Mountains. Sheep Creek and Lodgepole Creek also originate in the Uinta Mountains and flow along the southern border of the study area, eventually discharging into FGR. Other smaller perennial streams in the study area include Birch Spring Draw in the center of Lucerne Valley, and Antelope Wash in the northwestern part of the study area (fig. 1). The stream in Antelope Wash originates from springs that discharge within the study area and then flow to the northeast to merge with Henrys Fork. Numerous ephemeral streams are located in the study area.

The need to divert water for irrigation use was recognized early, prompting the construction of canal systems. Water for irrigation is obtained from drainages to the southwest along the flank of the Uinta Mountains and from Henrys Fork, and then diverted through canals into the valley. Peoples and Sheep Creek Canals are the principal diversions in the study area (fig. 1). Sheep Creek Canal diverts water for use in Lucerne Valley, South Valley, and Antelope Hollow. Water is generally discharged from Long Park Reservoir into Sheep Creek Canal from May to September. Discharge in the canal at the head of Lucerne Valley (site SCC-1) varied during this study. For example, the discharge measured in May 2004 was 100 $\mathrm{ft}^{3} / \mathrm{s}$ and the discharge measured in September 2004 was 34 $\mathrm{ft}^{3} / \mathrm{s}$ (table 2, located at back of report). The highest discharge measured was $126 \mathrm{ft}^{3} / \mathrm{s}$ in June 2005. Peoples Canal distributes water to irrigate lands in the lower part of Lucerne Valley. Water is generally diverted from Henrys Fork into Peoples Canal from April to November. Discharge at the head of the canal (site PC-1) varied during this study. For example, the discharge measured in June 2004 was $50 \mathrm{ft}^{3} / \mathrm{s}$ and the discharge measured in October 2004 was $24 \mathrm{ft}^{3} / \mathrm{s}$ (table 2).

Ground-water quality is highly variable among the aquifers present in the study area, even within the same hydrogeologic unit, and tends to increase in dissolved-solids concentration downgradient from recharge areas and with depth (Mason and Miller, 2004). Yields from wells in unconsolidated deposits along the floodplain of Henrys Fork are typically less than $10 \mathrm{gal} / \mathrm{min}$. Ground water is present in the Bridger aquifer in the Bridger Formation, where most of the sediments are of volcanic origin (Koenig, 1960). As a result, sulfate, fluoride, boron, iron, and manganese contribute to high dissolved-solids concentrations in ground water. The Laney aquifer (Green River Formation) has potential yields of as much as $75 \mathrm{gal} / \mathrm{min}$ and dissolved-solids concentrations ranging from 650 to 4,200 $\mathrm{mg} / \mathrm{L}$. Water in the Laney tends to be a sodium sulfate type. Ground-water discharge from the Green River Formation (fig. 2) is a substantial contributor to base-flow dissolved-solids loads in Henrys Fork (Mason and Miller, 2004).

The Wasatch aquifer typically produces as much as 500 $\mathrm{gal} / \mathrm{min}$. Water within the aquifer is quite variable and is typically a sodium bicarbonate or sodium sulfate type. Sulfate concentrations tend to be high in many areas, which can interfere with plant growth. Locally high concentrations of boron and fluoride also are present in ground water. Aquifers that yield small to moderate quantities of water suitable for domestic or agricultural use are contained within the Nugget (Navajo), Entrada, Morrison, and Dakota Formations.

\section{Previous Studies and Data-Collection Efforts}

Many studies of water resources and water chemistry have been completed in the upper Green River basin. A good synopsis of these is available in Mason and Miller (2004). Most of these studies have been regional in nature and do not provide much water-quality data specific to the agricultural lands near Manila. Hence, dissolved-solids data from surface- and ground-water resources in the agricultural lands near Manila are generally sparse prior to this study. However, about 500 samples from Henrys Fork near Manila (USGS station 


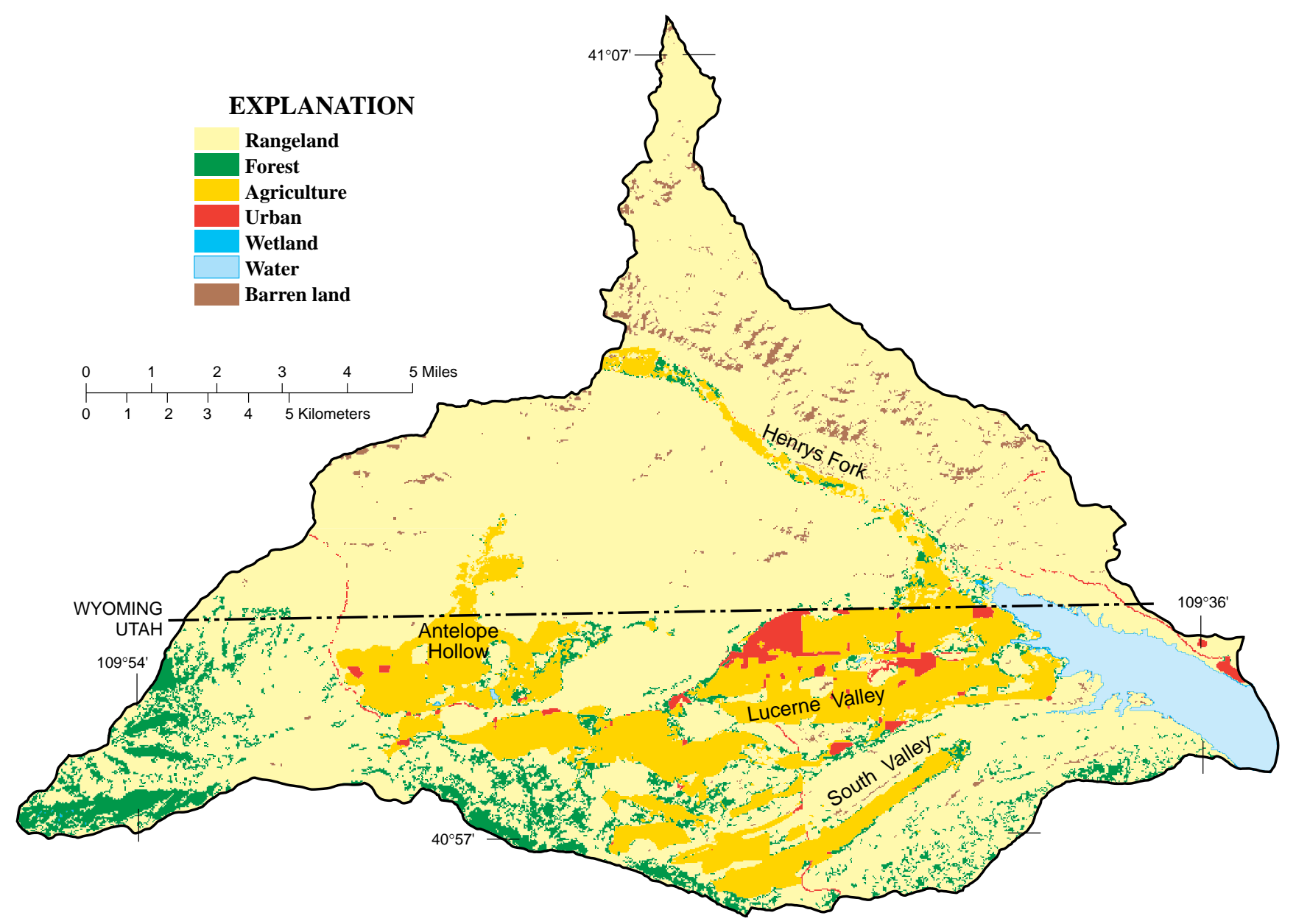

Figure 3. Land cover/use in the study area near Manila, Utah.

09229500), were collected by USGS personnel from 1954 to 1989 and analyzed for dissolved-solids concentration. These data are available from the USGS National Water Information System (NWIS) database. The U.S. Forest Service collected water samples from Birch Spring Draw at the Flaming Gorge National Recreation Area boundary from 2000 to 2003.

Sample analyses included dissolved-solids concentration and results are available from the U.S. Environmental Protection Agency STORET database. A preliminary investigation of dissolved solids in water resources in the agricultural areas near Manila was conducted by the NRCS and the Daggett County Soil Conservation District from 1991 to 1994 . Water conductivity and discharge were measured periodically at eight sites. These data are unpublished.

\section{Acknowledgments}

Landowners in the agricultural areas near Manila who provided access to sampling sites and cooperated in the process of sample collection are gratefully acknowledged. Jerry Steglich, Manila area landowner, is acknowledged for his considerable assistance with data collection and project coordination. NRCS personnel are acknowledged for provid- ing insight into salinity problems and agricultural practices in the study area.

\section{Methods of Investigation}

Drains, seeps, and streams transport dissolved solids from the study area into FGR. To estimate the total dissolved-solids load from these sources, a study approach was followed that included the periodic (synoptic) field measurement of discharge and water quality at all measurable flows from the study area (as many as 23 sites), and the regular or continuous field measurement of discharge and water quality at three fixed monitoring sites.

Continuous determination of dissolved-solids load at all sites discharging to FGR was not practical. Thus, regular and, during some time periods, continuous field measurements at the three largest drains in the study area were made to capture daily variability in dissolved-solids concentration and load and to provide a basis for estimating daily and annual dissolvedsolid loads discharging to FGR from the study area. 


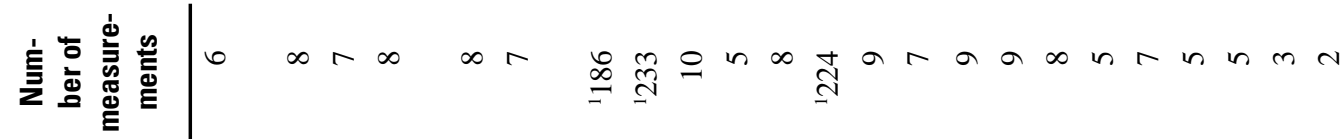

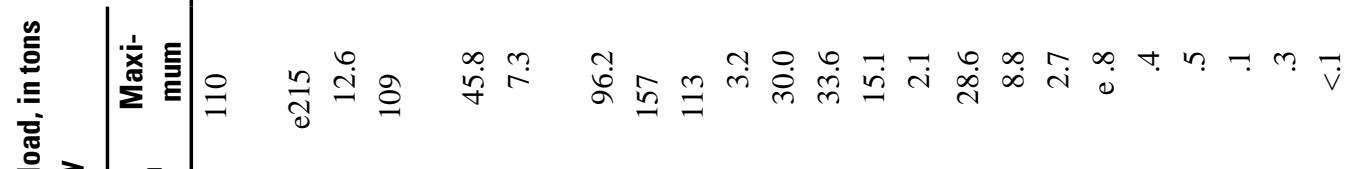

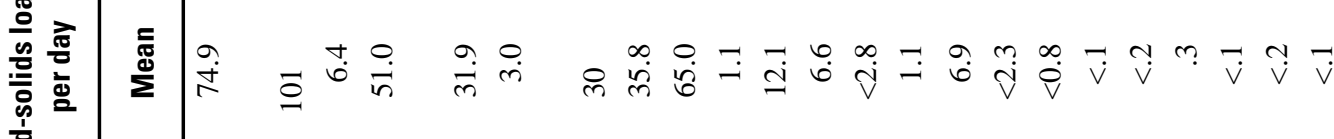

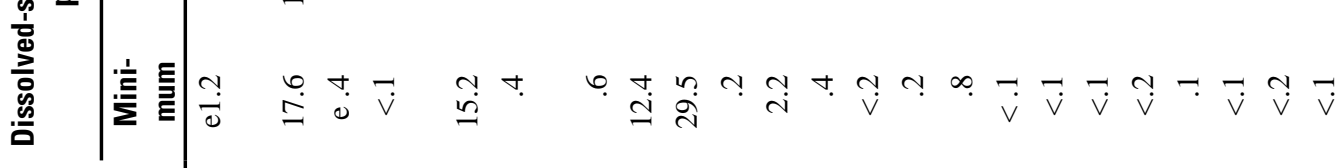

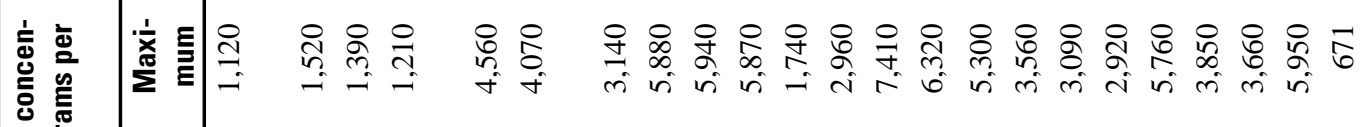

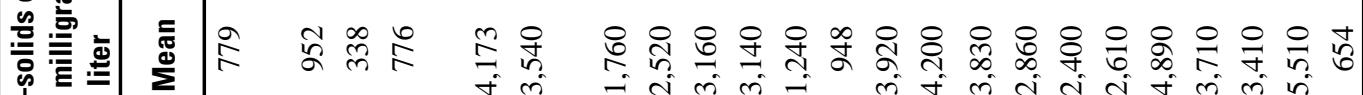

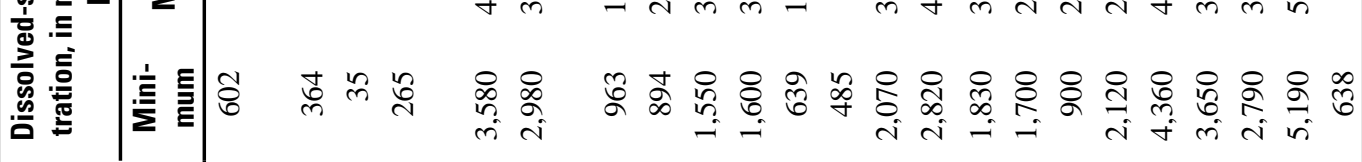

心

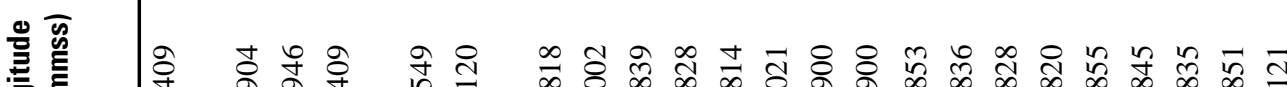

홓들

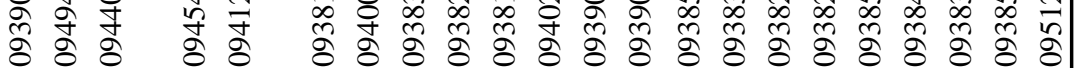

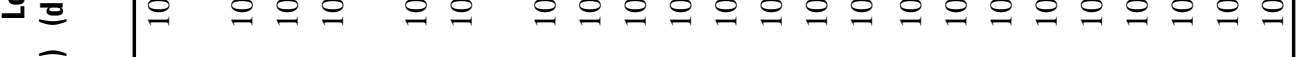

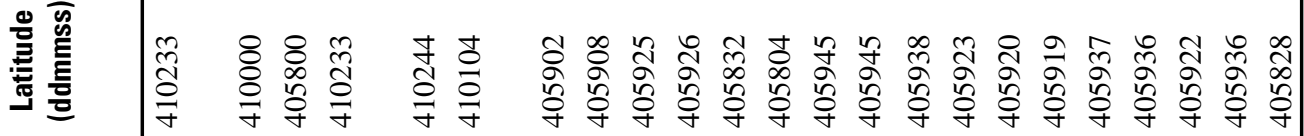

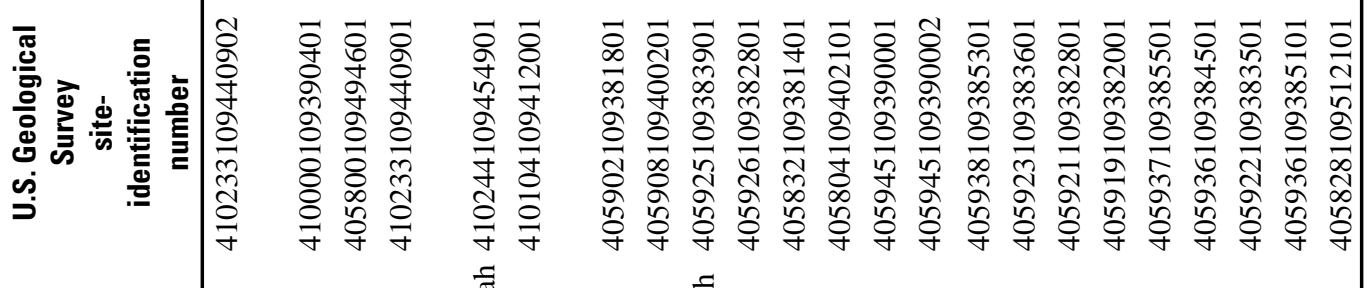

$\frac{\sum_{0}}{2}$

응

ָัָ

空

둫

$\frac{\mathscr{c}}{4}$

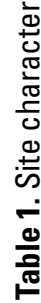

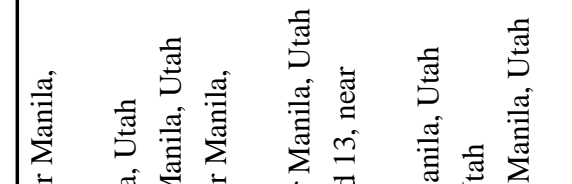

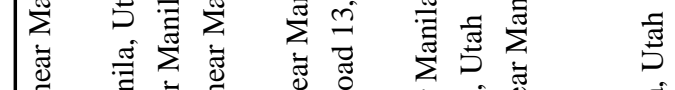

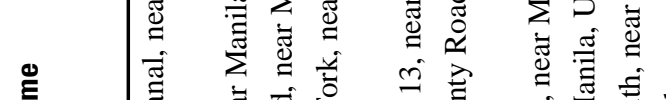

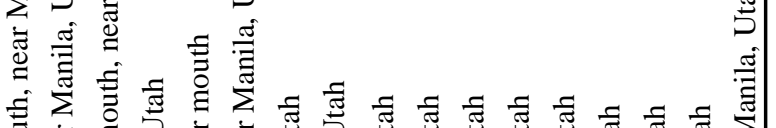

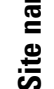

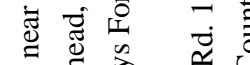

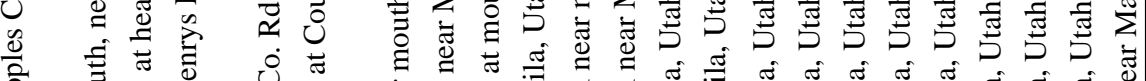

రั0

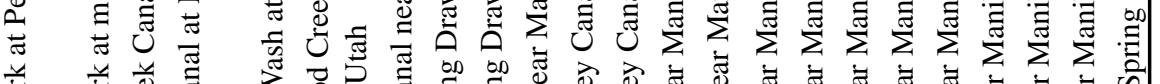

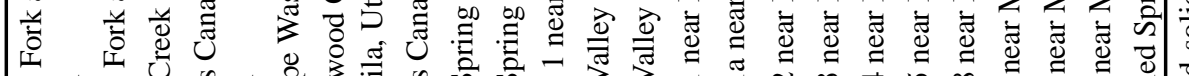

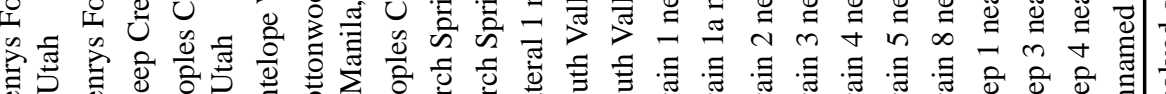

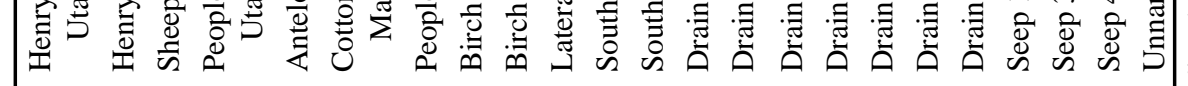

总离

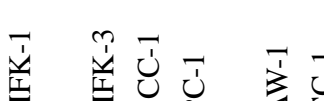

$\bar{z}$

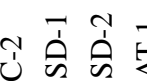

$\frac{\pi}{\dot{z}} \tilde{z} \dot{z} \dot{z} \tilde{z}$ 


\section{Data Collection}

\section{Daily Discharge and Specific Conductance}

Periodic measurements of discharge, specific conductance, and water temperature were made on canals and streams importing dissolved solids to the study area (three sites) and at all identifiable sites discharging dissolved solids to the reservoir (as many as 16 sites) during nine field trips between June 2004 and June 2005 (fig. 1, tables 1 and 2).

To capture the daily variability in discharge and dissolved-solids load, three fixed outflow-monitoring sites were established where measurements of stream stage and specific conductance were taken at more frequent intervals. These sites were established on the largest drains in the study area (Birch Spring Draw (BSD-1), Peoples Canal (PC-2), and South Valley (SV-1)) as near their outflow to FGR as practical. From July 1 to September 30, 2004, daily measurements of gage height and specific conductance were made at the fixed sites. Periodic measurements (averaging once every two weeks) of gage height and specific conductance were made from October 2004 to February 2005; however, as a result of field conditions and personnel and equipment constraints, there were no measurements of stage or specific conductance made for many of the days in this period. Continuous measurements (15-minute interval) of stage and specific conductance were made at BSD-1 and SV-1 from February 25 to June 30, 2005; however, daily measurements of gage height and specific conductance were made at PC-2 during this period.

Stage-discharge relations for the three fixed sites were defined by making instantaneous discharge and stage measurements on about a monthly basis. The shifting control method was applied to the stream stage (water-surface altitude relative to an arbitrary datum) record from the three sites to calculate discharge. This method of determining stream discharge is described in detail in Buchanan and Somers (1969) and Kennedy (1983). Data-collection frequency at these sites varied as a result of changing field conditions and the availability of equipment and personnel. The number of stage measurements that the mean daily discharge at the three monitoring sites was based on varied from 1 to 96 depending on whether the data were collected by a field observer or a field instrument with data-logging capabilities.

\section{Water-Quality Sample Collection, Processing, and Analysis}

Water-quality measurements were made at synoptic and fixed outflow-monitoring sites in the study area from May 2004 through June 2005. All site visits included on-site field measurement of discharge, specific conductance, and water temperature. Samples were collected at selected sites and analyzed for dissolved major ions (table 3, located at back of report) so that water types within the study area and their distribution could be determined. Water-quality samples from selected sites were analyzed for residue on evaporation at $180^{\circ} \mathrm{C}$ (ROE) so that subsequent calculations of dissolved-solids load could be made. Surface-water samples were collected with a depth-integrated, isokinetic sampler and applying the equal-width-increment (EWI) method when appropriate (Webb and others, 1999); however, samples from shallow or slow moving streams were collected from the center of flow into an open-mouth 1-liter polyethylene bottle. Water samples collected for analysis of dissolved constituents were filtered through a disposable 0.45 -micron capsule filter by using a peristaltic pump. Sample filtering and preservation were completed in the field.

Water samples were analyzed for the concentration of major ions at the USGS National Water Quality Laboratory (NWQL) in Lakewood, Colorado, with the standard analytical techniques described in Fishman and Friedman (1989). All data are stored in the USGS NWIS database. Analytical methods and minimum reporting limits for the analyzed properties and constituents are listed in table 4.

Water samples were collected from selected sites, filtered through a disposable 0.45 -micron capsule filter, and analyzed in the USGS stable isotope laboratory in Menlo Park, California, for strontium and boron, and the isotopic ratios of naturally occurring ${ }^{87} \mathrm{Sr}$ and ${ }^{86} \mathrm{Sr}$; and naturally occurring ${ }^{10} \mathrm{~B}$ and ${ }^{11} \mathrm{~B}$.

\section{Quality Control}

Quality-control samples were collected at selected sites to determine if data quality associated with water samples collected for this study is sufficient for water-quality assessments. Two types of quality-control samples were collected and analyzed: (1) field blanks to determine sample bias, and (2) concurrent replicates to determine sample variability. Results from analysis of these samples are available from the USGS NWIS database.

Field blanks were collected once each at sites BSD-2 and PC-2 and analyzed for alkalinity and the major ions listed in table 4 . None of the major ions were detected in amounts higher than the minimum reporting levels. The alkalinities of these samples, 3 and $5 \mathrm{mg} / \mathrm{L}$, were above the minimum reporting level but less than 5 percent of the amount detected in all of the environmental samples collected except those from site SCC-1. The alkalinity measured in water samples from site SCC-1 ranged from 16 to $26 \mathrm{mg} / \mathrm{L}$; consequently, if the alkalinity measured in the two field blanks was associated with systemic contamination, the results from analysis of water samples collected at SCC- 1 could have a positive bias, that in turn, would result in a positive bias in the determination of dissolved-solid loads at site SCC-1. However, the potential contamination would have resulted in a relatively small increase in the dissolved-solids load calculated to be imported to the study area and in the subsequent calculation of the dissolved-solids load discharging to FGR. 
Table 4. Field and analytical methods and minimum reporting levels for water-quality field measurements and constituent concentrations in samples collected from water-quality monitoring sites near Manila, Utah

$\left[\mathrm{ft} / \mathrm{s}\right.$, cubic feet per second; $\mu \mathrm{S} / \mathrm{cm}$, microsiemens per centimeter; ${ }^{\circ} \mathrm{C}$, degrees Celsius; $\mathrm{mg} / \mathrm{L}$, milligrams per liter; ICP, inductively coupled plasma; IC, ion chromatography]

\begin{tabular}{|c|c|c|c|c|}
\hline Measurement or constituent & Unit & Field method & Analytical method & $\begin{array}{c}\text { Minimum } \\
\text { reporting } \\
\text { level }\end{array}$ \\
\hline \multicolumn{5}{|c|}{ Physical Properties } \\
\hline Discharge, instantaneous & $\mathrm{ft}^{3} / \mathrm{s}$ & Mid-interval & - & Variable \\
\hline Specific conductance & $\mu \mathrm{S} / \mathrm{cm}$ at $25^{\circ} \mathrm{C}$ & Point & - & 1 \\
\hline Water temperature & ${ }^{\circ} \mathrm{C}$ & Point & - & .1 \\
\hline Alkalinity & $\mathrm{mg} / \mathrm{L}$ & - & Titration & 1 \\
\hline \multicolumn{5}{|c|}{ Major lons } \\
\hline Calcium, dissolved, as $\mathrm{Ca}$ & $\mathrm{mg} / \mathrm{L}$ & - & ICP & .1 \\
\hline Chloride, dissolved, as $\mathrm{Cl}$ & $\mathrm{mg} / \mathrm{L}$ & - & IC & .1 \\
\hline Fluoride, dissolved, as F & $\mathrm{mg} / \mathrm{L}$ & - & Ion-selective electrode & .1 \\
\hline Hardness, total, as $\mathrm{CaCO}_{3}$ & $\mathrm{mg} / \mathrm{L}$ & - & Calculated & 1 \\
\hline Magnesium, dissolved, as $\mathrm{Mg}$ & $\mathrm{mg} / \mathrm{L}$ & - & ICP & .1 \\
\hline Potassium, dissolved, as $\mathrm{K}$ & $\mathrm{mg} / \mathrm{L}$ & - & ICP & .1 \\
\hline Silica, dissolved, as $\mathrm{Si}$ & $\mathrm{mg} / \mathrm{L}$ & - & ICP & .1 \\
\hline Sodium, dissolved, as $\mathrm{Na}$ & $\mathrm{mg} / \mathrm{L}$ & - & ICP & .1 \\
\hline Sulfate, dissolved, as $\mathrm{SO}_{4}$ & $\mathrm{mg} / \mathrm{L}$ & - & IC & .1 \\
\hline Solids, dissolved, sum of constituents & $\mathrm{mg} / \mathrm{L}$ & - & Calculated & 1 \\
\hline Solids, dissolved, residue on evaporation (ROE) at $180^{\circ} \mathrm{C}$ & $\mathrm{mg} / \mathrm{L}$ & - & Gravimetric & 10 \\
\hline
\end{tabular}

A concurrent replicate sample was collected at site AW-1 and analyzed for alkalinity and the major ions listed in table 4. The difference in the concentration of those parameters between the two samples was less than 5 percent. Additionally, concurrent replicate ROE samples were collected once at sites PC-1, BSD-1, and SV-1. The difference in ROE between each of the two samples was less than 3 percent. Results from the concurrent replicate samples collected during this study indicate that field and laboratory methods did not significantly affect the variability of results from water-quality sampling.

\section{Data Analysis}

\section{Dissolved-Solids Concentration Estimates}

Specific conductance is a measure of the capacity of water to conduct an electrical current and is a function of the types and quantities of dissolved solids in water (Radke and others, 2005). The USGS reports specific conductance in microsiemens per centimeter at $25^{\circ} \mathrm{C}\left(\mu \mathrm{S} / \mathrm{cm}\right.$ at $\left.25^{\circ} \mathrm{C}\right)$. As the concentration of dissolved solids increases, the specific-conductance value of the water increases; hence, specific-conduc- tance measurements provide a good indication of dissolvedsolids concentration. A relation between specific conductance and dissolved-solids concentration generally exists in many water sources. This allows specific conductance to be used in conjunction with chemical analyses to estimate dissolvedsolids concentration and load. This relation, expressed as the ratio of dissolved-solids concentration (from ROE) to specific conductance, was established at all sites. Sites were grouped by type (stream, canal, drain, seep, or spring) and an average dissolved-solids/specific-conductance ratio was determined for each type so that this average ratio could be used to estimate dissolved-solids concentration at sites with no chemical data. The relation between dissolved-solids concentration and specific conductance at water-quality monitoring sites in the study area varied spatially and temporally. For example, the mean dissolved-solids/specific-conductance ratio at site BSD-2 was 0.82 (table 2), but the mean dissolved-solids/specific-conductance ratio at site AW-1 was 1.0. The dissolved-solids/specific conductance ratio at site BSD-2 ranged from 0.75 to 0.89 .

Higher dissolved-solids/specific-conductance ratios were generally associated with water containing higher concentrations of sodium and sulfate and lower ratios were associated with calcium bicarbonate type water. 


\section{Dissolved-Solids Load Calculations}

The approach to calculating the dissolved-solids load discharged from the study area between July 1, 2004, and June 30, 2005, involved a multiple-step process. First, dissolvedsolids loads being transported into the study area and being discharged from the study area to FGR were calculated for each of nine periodic visits to the study area. The dissolvedsolids load imported to the study area through Sheep Creek Canal and in Henrys Fork was calculated and subtracted from the total load calculated for the 15 sites that were identified as discharging water to FGR. This resulted in a total adjusted dissolved-solids load (TADSL) that could be attributed to agricultural activities in the Manila area. Concurrently, the dissolved-solids load at the three fixed outflow-monitoring sites on the main drains discharging to FGR was determined. The relation between the load calculated for the fixed outflowmonitoring sites and the TADSL discharging from the Manila study area was determined. For each day that data were collected at the three fixed outflow-monitoring sites, a daily mean dissolved-solids load was calculated. For days when no data were collected at the fixed outflow-monitoring sites, no daily mean dissolved-solid loads were estimated. The daily dissolved-solids load values at the fixed outflow-monitoring sites and the relation between the dissolved-solids load at the fixed outflow-monitoring sites and the TADSL (fig. 4) were used to estimate the daily TADSL discharged from the study area.
The TADSL discharged from the study area has a predictable relation to the dissolved-solids load at the three fixed outflow-monitoring sites. A regression model that was used to describe the relation of the TADSL and the dissolved-solids load at the fixed outflow-monitoring sites is shown in equation 1:

$$
\text { TADSL }=59.4854+0.8394 M L+e
$$

where:

TADSL is the total measured dissolved-solids load (less the dissolved-solids load in inflow to the study area), discharged from the study area, in tons/d;

$M L \quad$ is the monitored dissolved-solids load at fixed outflow-monitoring sites, in tons/d; and

e is the residual error.

On the right side of the equation, the variable $\mathrm{ML}$ accounts for variability in TADSL relative to the load at fixed outflow-monitoring sites. The overall F-test statistic (27.83 on 1 and 7 degrees of freedom) for this model has a p-value of 0.001 . This indicates that the apparent relation of the explanatory variable and TADSL was not likely to arise by chance alone. The coefficient of determination (R-squared) for this model is 0.80 .

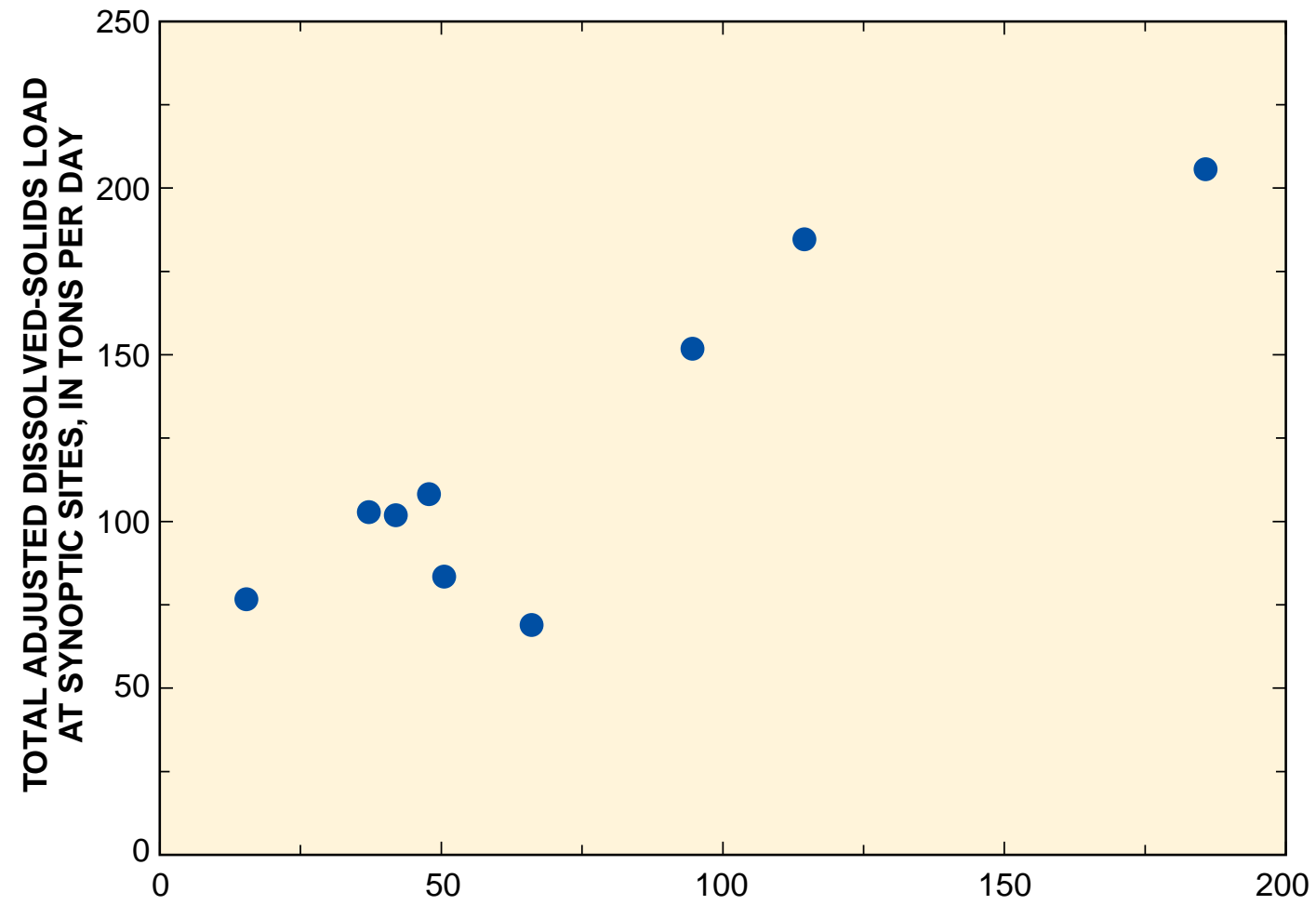

TOTAL DISSOLVED-SOLIDS LOAD AT FIXED LOAD-MONITORING SITES, IN TONS PER DAY

Figure 4. Relation of total adjusted dissolved-solids load at synoptic sites and total dissolved-solids load at fixed outflowmonitoring sites near Manila, Utah. 
Daily mean dissolved-solids load calculated for the fixed outflow-monitoring sites was applied to equation 1 to determine daily TADSL. For periods with missing data at the fixed outflow-monitoring sites, the daily TADSL was estimated by projecting the calculated daily TADSL at the beginning and end of those periods to the midpoint of the period. Estimates of daily TADSL were summed to calculate an estimated annual TADSL.

\section{Calculation of Salt-Loading Factor}

One measure of the potential for movement of dissolved solids from the agricultural lands near Manila to FGR is the difference between the amount of dissolved solids in water distributed for irrigation and the amount of dissolved solids in ground water discharging into FGR. The difference is the amount of salt accumulated in ground water that could possibly be attributed to deep percolation of unconsumed irrigation water. This measure was termed a "salt-loading factor" by Hedlund (1994) and is reported in units of tons of dissolved solids per acre-foot (acre-ft) of deep percolation. Deep percolation is defined as water that has been applied to irrigated fields but has seeped below the root zone and is unconsumed by crops, or water that has seeped from irrigation delivery systems and is likewise not consumed or evaporated. The saltloading factor assumes that all the ground water discharging from seeps and drains entered the aquifer from deep percolation of unconsumed irrigation water.

A salt-loading factor for the study area was determined by subtracting the flow-weighted mean dissolved-solids concentration in canals from the mean dissolved-solids concentration in seeps and drains discharging to FGR. Because the dissolved-solids concentration of water distributed in canals changes throughout the irrigation season, a flow-weighted mean dissolved-solids concentration was used as a descriptive statistic for the water applied to fields. Measurements in seeps and drains that were used in the calculation of the mean dissolved-solids concentration were from samples collected during the non-irrigation period, November to April, when nearly all the flow was from ground-water discharge.

\section{Characterization of Dissolved Solids in Water Resources}

\section{Occurrence and Distribution of Dissolved Solids}

The major-ion composition of study area waters varies substantially, with much of the surface inflow to the area being calcium bicarbonate type water (fig. 5, group A) and most of the surface outflow being calcium sulfate type water (fig. 5, group B). Water imported to the Manila agricultural area canal system in Sheep Creek Canal is generally calcium bicarbonate type water; however, the water imported through Peoples Canal varies from calcium bicarbonate type water early in the irrigation season when snowmelt is a substantial component of flow, to calcium magnesium sulfate type water later in the irrigation season when irrigation return and ground-water discharge in upstream basins of Henrys Fork are the dominant flow components. Water discharged from drains and seeps near the FGR shoreline is generally more mineralized than water imported to the study area by the canal system and is probably derived primarily from irrigation return flow. Deep percolation of irrigation water applied in excess of crop consumptive use results in dissolution of salts from soils derived from the Mancos Shale underlying Lucerne Valley. Sulfate is the predominant anion in water from most of the drains and seeps discharging to FGR from the study area (table 5, fig. 5). Cations in water from these drains and seeps are predominantly calcium, magnesium, and sodium. Water discharging from South Valley to FGR is generally less mineralized than that discharging from Lucerne Valley and is more of a mixed type. The difference in water types discharging from South Valley and Lucerne Valley is probably a result of the difference in underlying geologic units and soil types. Although the dissolved-solids concentration in water samples collected at the mouth of Henrys Fork was higher than that in water samples collected in the upper part of the valley at the Peoples Canal diversion, the relative major-ion composition of the water was similar. Antelope Wash, at site AW-1, had the largest relative amount of sulfate of any water sampled in the study area. Discharge, dissolved-solids concentration, and relative composition of major ions in the water at the mouth of Antelope Wash were fairly stable during the study period, probably because of the influence of numerous springs in this subbasin.

In the study area, concentrations of dissolved solids (measured or estimated from specific-conductance measurements) ranged from 35 to 7,410 mg/L (tables 1 and 2, fig. 6). The dilute water diverted into Sheep Creek Canal transports a relatively small amount of dissolved solids into the study area; about 13 tons/d at peak discharge. Concentrations of dissolved solids in Sheep Creek Canal (at site SCC-1) were generally less than $100 \mathrm{mg} / \mathrm{L}$ during periods when water was being diverted into the canal from Long Park Reservoir (fig. 1). Two measurements of specific conductance were made in Sheep Creek Canal (at site SCC-1) when all flow was from seepage in the vicinity of site SCC-1. The dissolved-solids concentration based on specific conductance in the canal at the time of these measurements was 770 and 1,390 mg/L; however, the discharge associated with both measurements was less than 0.3 $\mathrm{ft}^{3} / \mathrm{s}$. Water diverted into Peoples Canal (at site PC-1) transports a substantial amount of salt into the agricultural lands near Manila, as much as 109 tons/d. Concentrations of dissolved solids in water diverted from Henrys Fork into Peoples Canal (at site PC-1) ranged from 265 to $1,210 \mathrm{mg} / \mathrm{L}$.

The dissolved-solids concentration at the mouth of Birch Spring Draw (site BSD-2) varied from 1,550 to 5,940 mg/L. The higher concentrations occurred during base flow when 
Table 5. Relative percentage of major ions in selected water samples collected at water-quality monitoring sites near Manila, Utah $[<$, less than $]$

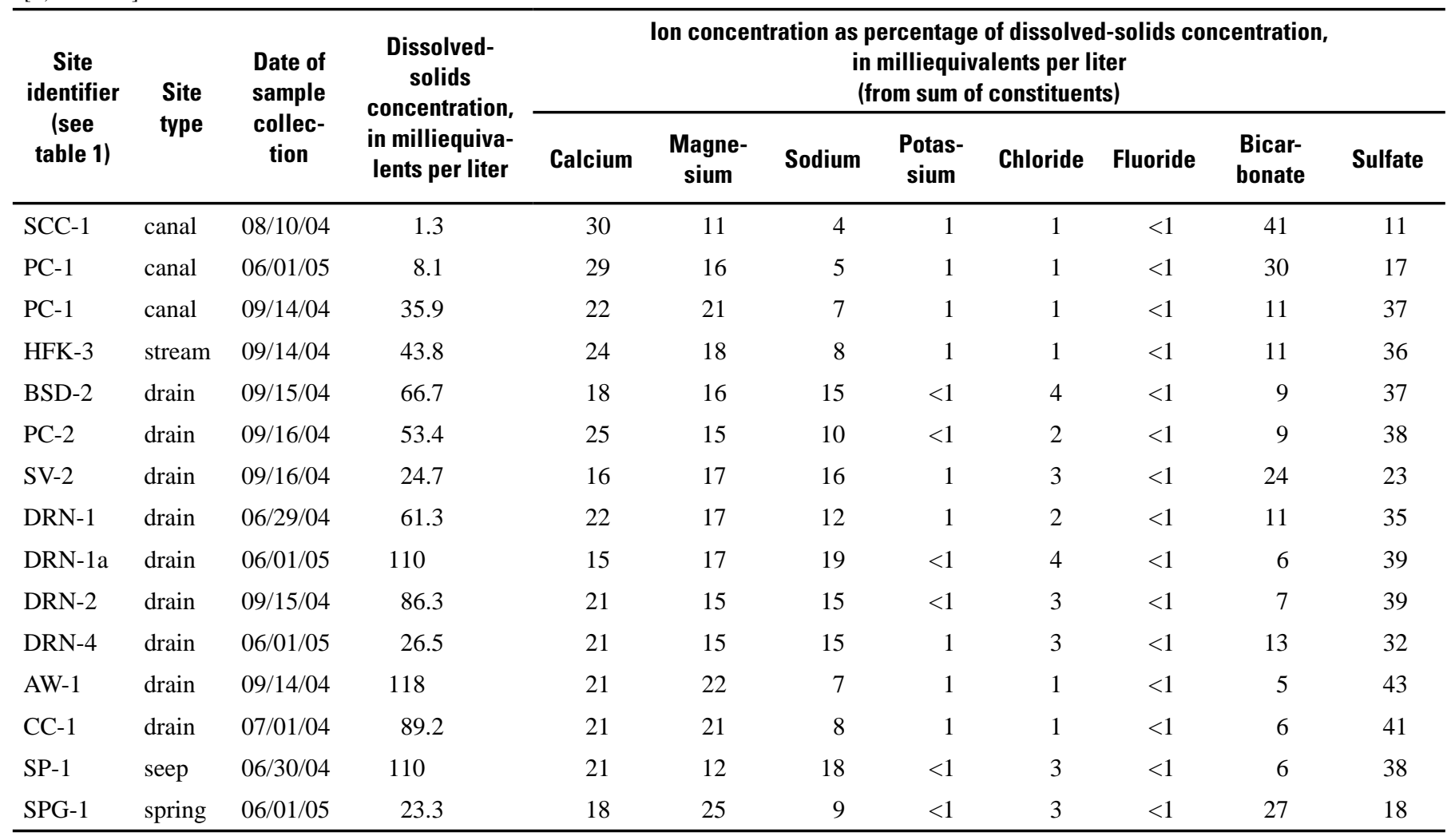

ground water was the principal component of flow; lower concentrations were the result of more dilute canal tailwater making up a substantial component of flow. Calculated dissolved-solids loads discharging from Birch Spring Draw (at site BSD-1) were as much as 157 tons/d. Calculations of the dissolved-solids load in Birch Spring Draw show that on average the dissolved-solids load increases about 32 percent from site BSD-1 to site BSD-2. Field observations indicate that there is little surface inflow but substantial ground-water discharge to Birch Spring Draw in the reach between BSD-1 and BSD-2.

Water samples from all measured drains discharging to Henrys Fork or FGR had dissolved-solids concentrations ranging from 555 to $7,410 \mathrm{mg} / \mathrm{L}$ (fig. 6). The dissolved-solids load in these drains at the time of sample collection ranged from less than 0.1 ton/d to 113 tons/d. Seeps that were measured near the FGR shoreline generally discharged less than $0.1 \mathrm{ft}^{3} / \mathrm{s}$ and had concentrations of dissolved solids ranging from 2,790 to $5,950 \mathrm{mg} / \mathrm{L}$. The dissolved-solids load discharging from individual seeps was generally less than 0.5 ton/d.

\section{Discharge of Dissolved Solids into Flaming Gorge Reservoir}

The dissolved-solids load discharging to FGR from seeps and drains in the study area ranged from 157 tons/d at Birch
Spring Draw to less than 0.1 ton/d at several seeps. During the study period, the water-surface altitude of FGR rose from 6,009 ft to 6,026 ft (Bureau of Reclamation, written commun., 2005); the water-surface altitude when the reservoir has a full pool is $6,040 \mathrm{ft}$. The unusually low water-surface altitude of FGR during most of the study period made observations of seeps on the reservoir shoreline below the full-pool altitude possible. The dissolved-solids load discharging from seeps that were visited was generally less than 0.5 ton/d. The dissolved-solids load discharging into FGR from Henrys Fork ranged from 18 to 215 tons/d; however, no loads were determined for the period of snowmelt runoff when dissolvedsolid loads would be much higher, but generally from sources outside the study area.

The most substantial source of dissolved solids discharging from the study area to FGR was Birch Spring Draw. The dissolved-solids load at site BSD-2, at the mouth of Birch Spring Draw, ranged from 29.5 to 113 tons/d with a mean of 65 tons/d (table 1). Loads discharged from Birch Springs Draw were more variable than those at other sites (standard deviation equals 30 tons/d), probably because of the numerous irrigation diversions affecting flow in the drain. The second most substantial source of dissolved solids was Antelope Wash. Flow components in this drain include discharge from numerous springs and return flow from irrigation in Antelope Hollow. Dissolved-solid loads near the mouth of Antelope Wash (site AW-1) ranged from 15.2 to 45.8 tons/d. Dissolved- 


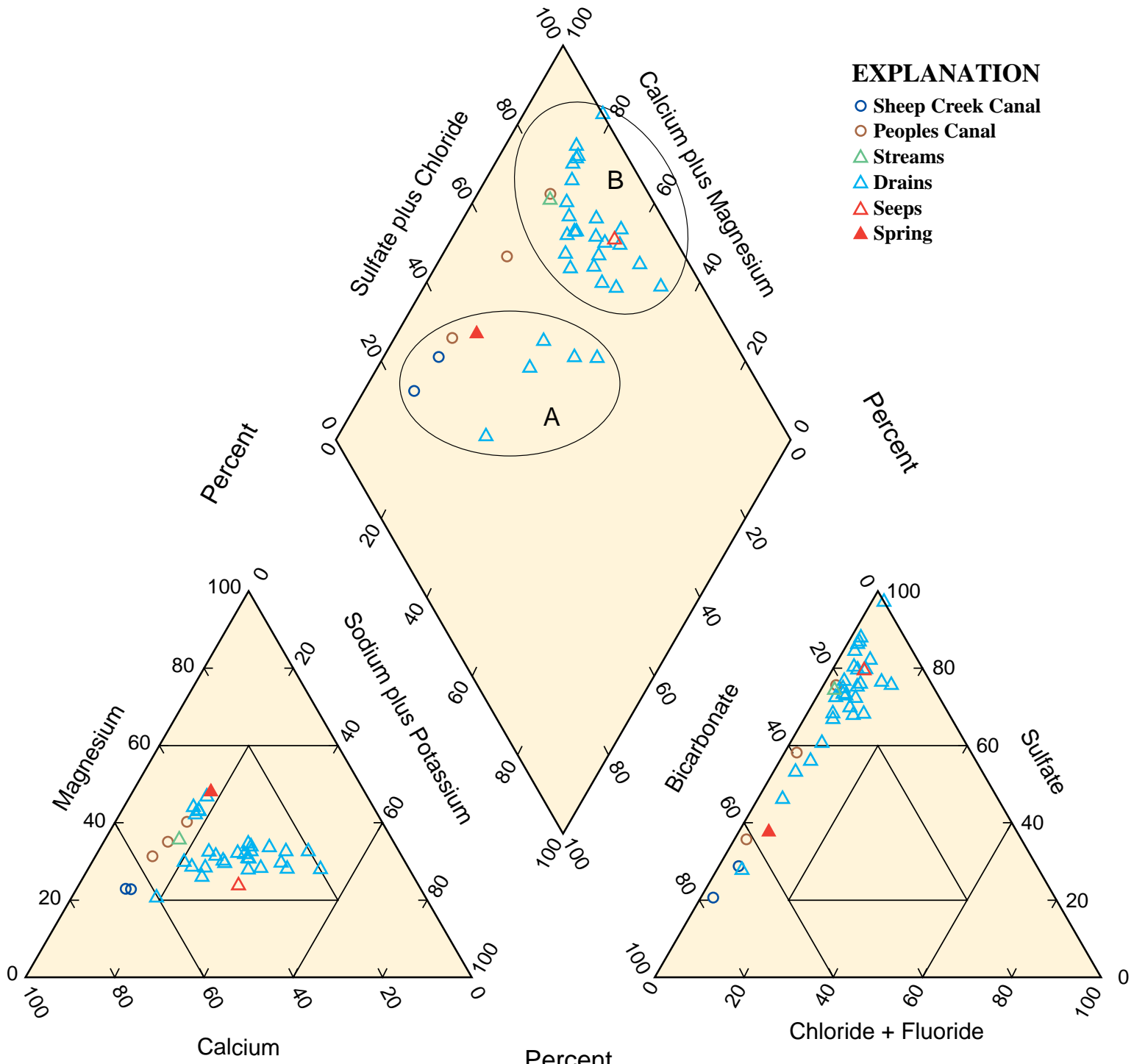

Figure 5. Relative composition of water in the study area near Manila, Utah

solid loads from Antelope Wash and South Valley (site SV-2) were relatively constant, having a mean of 31.9 and 12.1 tons/d, respectively, and a standard deviation of 11 and 10 tons/d, respectively. The dissolved-solid loads at site PC-2 at the tail of Peoples Canal ranged from 0.6 to 96.2 tons/d with a mean of 30 tons/d. Dissolved-solid loads at this site were variable; the standard deviation being 20 tons/d. Smaller drains, in particular those at sites DRN-1 and DRN-2, discharged a substantial amount of dissolved solids to FGR, as much as 28.6 tons/d. Dissolved-solid loads in these drains were extremely variable; however, they were generally greatest during June through August.

A substantial amount of dissolved solids is transported into, and distributed throughout, the study area by Sheep Creek Canal and Peoples Canal. An estimate was determined of the amount of dissolved solids diverted into these canals during the 2004 irrigation season (table 6). These estimates are based on instantaneous measurements of flow and dissolvedsolids concentration and assume there was flow in Sheep Creek Canal from May 1 to September 30 and in Peoples Canal from April 1 to October 31. The total estimated dissolved-solids load in Sheep Creek Canal and Peoples Canal was 1,330 and 13,200 tons, respectively. The water diverted into Sheep Creek Canal from Long Park Reservoir is mainly composed of snowmelt and has a low concentration of dissolved solids. As a result, the dissolved-solids load in Sheep Creek Canal is relatively small compared to that in Peoples Canal even though Sheep Creek Canal generally has more flow. The water diverted into Peoples Canal has a substantial snowmelt component in the spring, but ground-water discharge and irrigation return flow, which have high dissolvedsolid concentrations, are the major components in summer. 

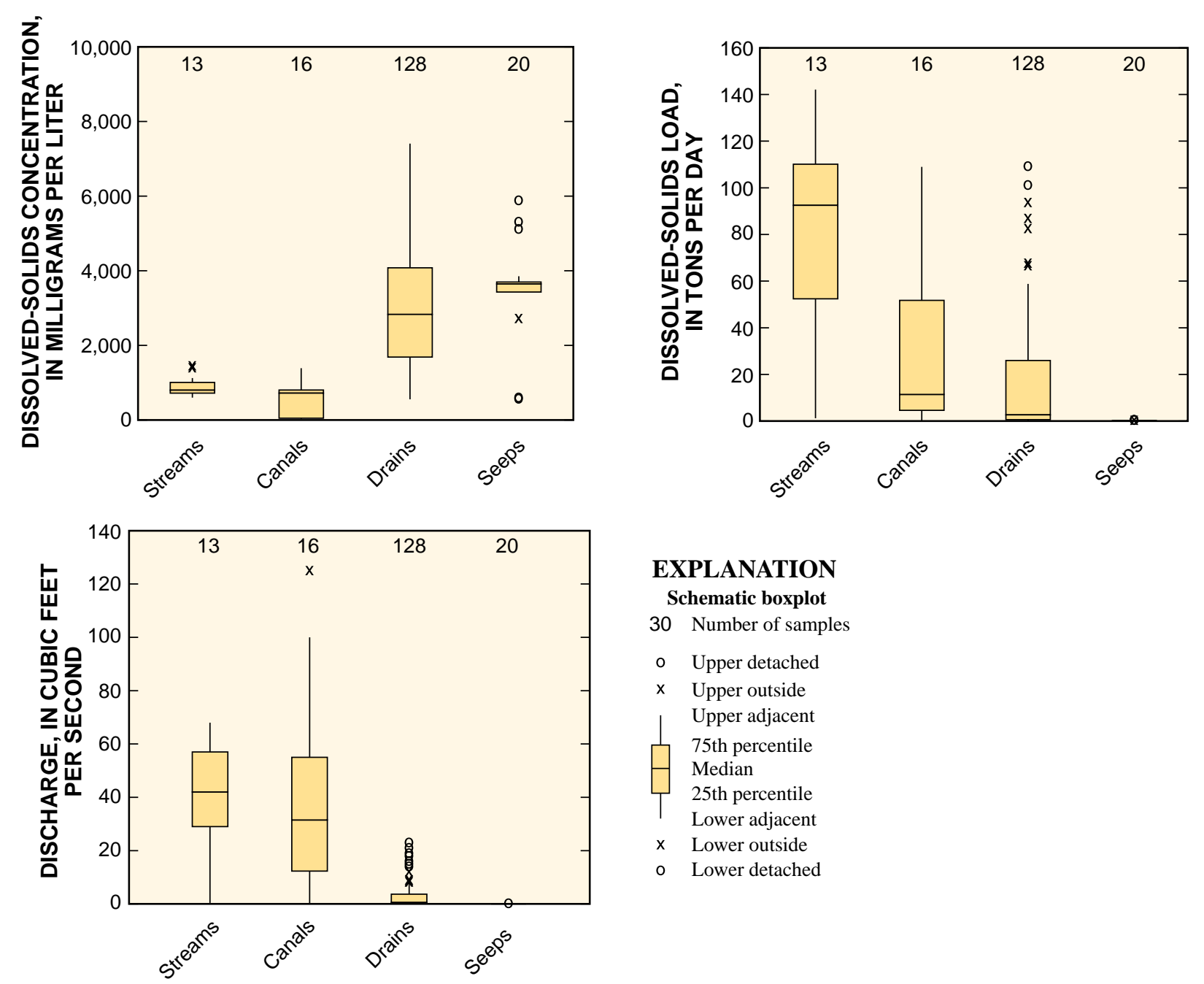

\section{EXPLANATION \\ Schematic boxplot \\ 30 Number of samples \\ - Upper detached \\ $x$ Upper outside \\ Upper adjacent \\ 75th percentile \\ Median \\ 25th percentile \\ Lower adjacent \\ $x$ Lower outside \\ - Lower detached}

Figure 6. Distribution of dissolved-solids concentration and load, and discharge at water-quality monitoring sites near Manila, Utah.

Hence, the water diverted from Henrys Fork through Peoples Canal is a substantial source of dissolved solids to agricultural lands in the study area.

The dissolved-solids load in inflow to the study area, outflow to FGR, and at three fixed outflow-monitoring sites is listed in table 7. As previously described, these data were used to determine daily TADSLs, which were then aggregated to determine an annual TADSL. A time-series plot of daily TADSL, with a locally weighted scatter plot smooth (LOWESS), shows the variation in daily TADSL as well as the seasonal changes. Substantial daily variability is evident by the scatter in data points shown on figure 7 for those periods when data were collected at the fixed outflow-monitoring sites. Linear changes are shown for those periods that daily TADSLs were estimated. Daily TADSLs were greatest during July and early August 2004, stayed relatively high through January 2005, and then declined February through early April (fig. 7). Loads began increasing in mid-April and by June had returned to near the level noted during the previous July. Daily TADSL ranged from 72 to 241 tons/d with a mean of 110 tons/d. A time-series plot of the cumulative TADSL shows that discharge from the study area during this period was relatively constant (fig. 8).

The aggregate of the daily TADSLs calculated from equation 1 for July 1, 2004, to June 30, 2005, is 40,200 tons. This aggregate value represents the measurable dissolved solids discharging from the study area, less the dissolved solids that were imported to the study area in Sheep Creek Canal and in Henrys Fork. Included in the aggregated TADSL are dissolved solids that may have been imported in atmospheric deposition, or are associated with ground water or surface runoff whose origin was something other than irrigation flow. Not included in the TADSLs are dissolved solids that may have been in ground water discharged below the surface of FGR. The aggregated TADSL should be considered an upper bound to the total dissolved-solids load that was (1) discharged to FGR, (2) from those sources that were measured, (3) during the stated period, and (4) that could be associated with agricultural activities in the study area. 
Table 6. Estimated dissolved-solids load in Sheep Creek Canal and Peoples Canal near Manila, Utah, April-October 2004

$[-$, no estimate $]$

\begin{tabular}{|c|c|c|c|}
\hline \multirow{2}{*}{ Period } & \multicolumn{2}{|c|}{$\begin{array}{l}\text { Estimated daily dissolved- } \\
\text { solids load, in tons per day }\end{array}$} & \multirow{2}{*}{$\begin{array}{l}\text { Estimated dis- } \\
\text { solved-solids } \\
\text { load, total for } \\
\text { period for both } \\
\text { canals, in tons }\end{array}$} \\
\hline & $\begin{array}{l}\text { Sheep Creek } \\
\text { Canal }\end{array}$ & $\begin{array}{l}\text { Peoples } \\
\text { Canal }\end{array}$ & \\
\hline April & - & 229 & 870 \\
\hline May & 10.2 & 229 & 1,220 \\
\hline June & ${ }^{2} 12.6$ & 109 & 3,650 \\
\hline July & 9.2 & 86.6 & 2,970 \\
\hline August & 6.3 & 49.7 & 1,740 \\
\hline September & 5.3 & 78.3 & 2,510 \\
\hline October & - & 51 & 1,580 \\
\hline \multicolumn{4}{|c|}{ Estimated total dissolved-solids load, in tons } \\
\hline April-October & 1,330 & 13,200 & 14,500 \\
\hline
\end{tabular}

${ }^{1}$ Estimated daily dissolved-solids load is based on a calculated instantaneous dissolved-solids load.

${ }^{2}$ Estimated daily dissolved-solids load is based on an instantaneous dissolved-solids load calculated for June 2005.
The chemistry, discharge, and consistent nature of flow measured in Antelope Wash indicate that Antelope Spring, the principal source of flow in the wash, could be discharging from a regional ground-water source, possibly from the Bridger aquifer. A more conservative estimate of the dissolved solids discharging to FGR that are associated with agricultural activities in the study area might be derived if the dissolved solids in base flow from Antelope Wash were not included. The mean dissolved-solids load in Antelope Wash (at site AW1) during the non-irrigation period was 24.7 tons/d. Assuming this is the mean base-flow dissolved-solids load and that it is associated with discharge from a regional ground-water source such as the Bridger aquifer, extrapolating that load to an annual basis results in an estimated annual discharge of 9,000 tons of dissolved solids from a regional source. Subtracting the 9,000 tons of dissolved solids from the aggregate TADSL results in a more conservative estimate of 31,200 tons of dissolved solids discharging to FGR from the study area (fig. 8).

The dissolved-solids load estimates derived here were determined for the specific period July 1, 2004, through June 30, 2005. The dissolved-solids load discharging to FGR from the study area for other periods may be substantially differ-

Table 7. Dissolved-solids load at inflow, outflow, and fixed outflow-monitoring sites in the study area near Manila, Utah

[Data are from table 2 and are instantaneous measurements made in the month indicated; —, no measurement; e, estimated value]

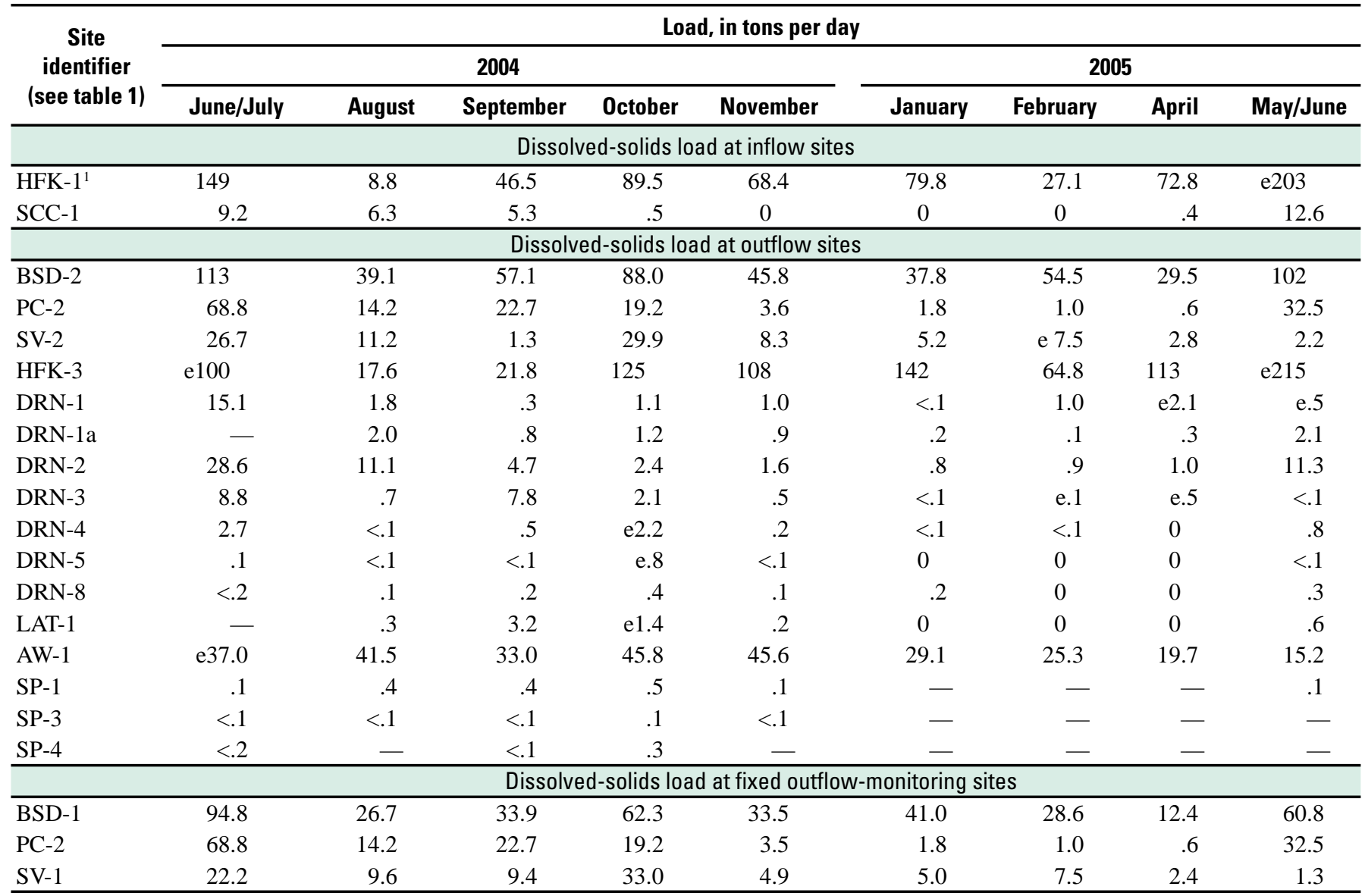

${ }^{1}$ Values are calculated by summing dissolved-solids loads at the head of Peoples Canal and in Henrys Fork directly below the Peoples Canal diversion, then subtracting the load that was discharged to Henrys Fork from Antelope Wash (site AW-1). 


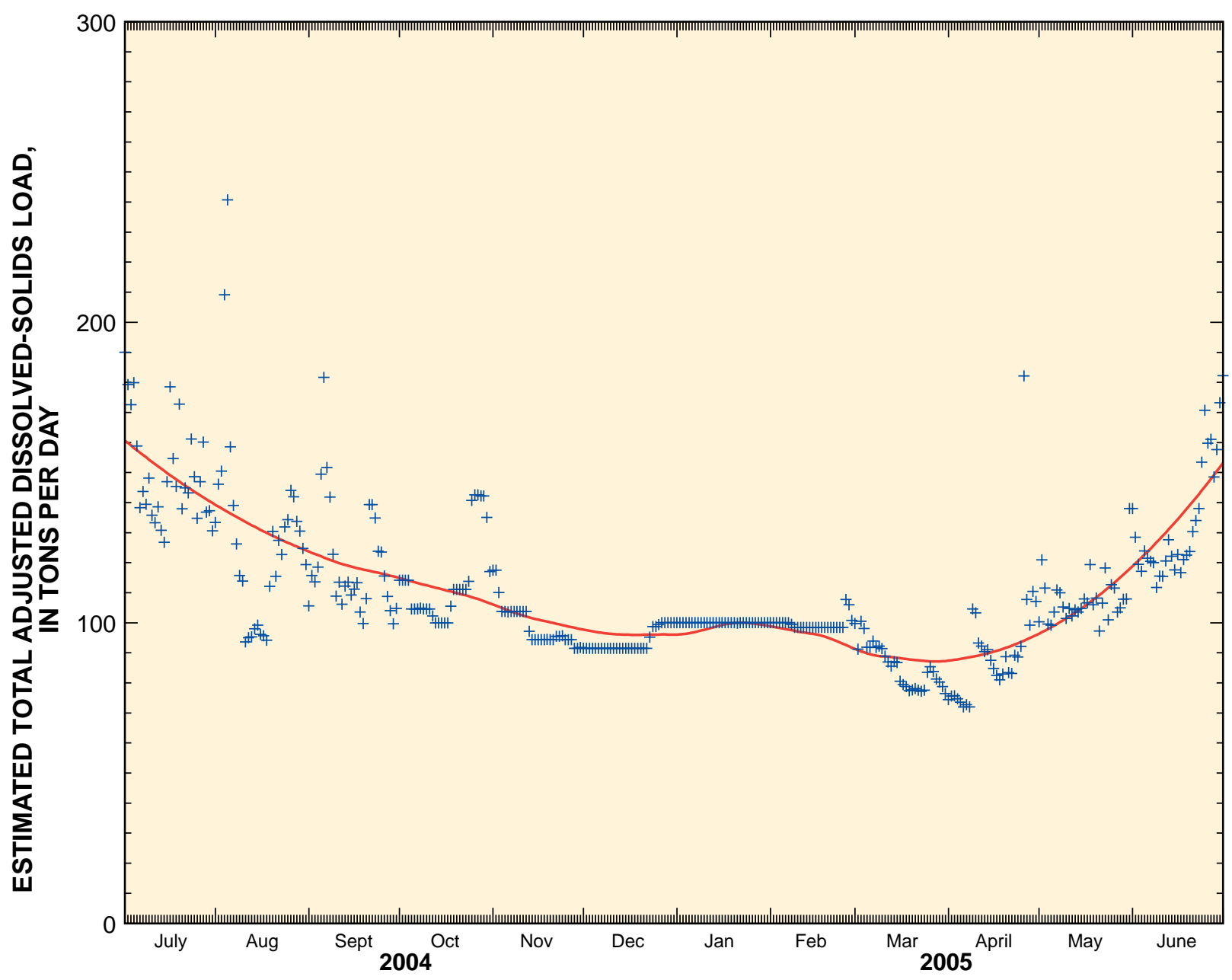

Figure 7. Estimated daily total adjusted dissolved-solids load discharged from the study area near Manila, Utah, July 1,2004 , through June 30, 2005. Points are daily total adjusted dissolved-solids load and line is locally weighted scatter plot smooth (LOWESS).

ent depending upon dispersement of irrigation water, annual precipitation, and other climatic factors. Precipitation in the study area was slightly greater than normal during this period (9.5 in., Western Regional Climate Center, 2005); however, precipitation during most of the irrigation season, May through September, was near or less than normal (table 8). Precipitation in October 2004 was substantially greater than normal and may have helped sustain the amount of dissolved solids discharging to FGR through February 2005. Flow in Peoples Canal is dependent upon flow in Henrys Fork and can be limited in years with less-than-normal precipitation. Flow in Peoples Canal may have been limited by less-than-normal streamflow in Henrys Fork during July-October 2004 and June 2005 (table 8). Discharge measurements from July 1, 2004, through June 30, 2005 (table 2), indicate that flow in the Sheep Creek Canal system was probably adequate for normal operation. On the basis of precipitation, canal flow, and streamflow in the study area from July 1, 2004, through June 30, 2005, the dissolved-solids load discharging to FGR during this period is likely normal to slightly less than normal.

\section{Salt-Loading Factor}

The flow-weighted mean concentration of dissolved solids distributed to Lucerne Valley by Sheep Creek and Peoples Canals was $268 \mathrm{mg} / \mathrm{L}$. This concentration is based on measurements of discharge and specific conductance or dissolved solids at the head of the canals during the irrigation season (table 9). The concentration of dissolved solids in water samples collected from seeps and drains from November 2004 through April 2005 is representative of ground-water discharge that is assumed to result from deep percolation of unconsumed irrigation water. The mean dissolved-solids concentration in water collected from seeps and drains in Lucerne Valley during this period was $3,940 \mathrm{mg} / \mathrm{L}$. The increase in dissolvedsolids concentration, as a result of processes occurring along the flow paths followed by deep percolation, is $3,670 \mathrm{mg} / \mathrm{L}$ or about 5 tons of dissolved solids per acre-ft of deep percolation in Lucerne Valley. Because the underlying geology and soils in South Valley are less saline than those in Lucerne Valley (fig. 2), the salt-loading factor associated with deep percola- 


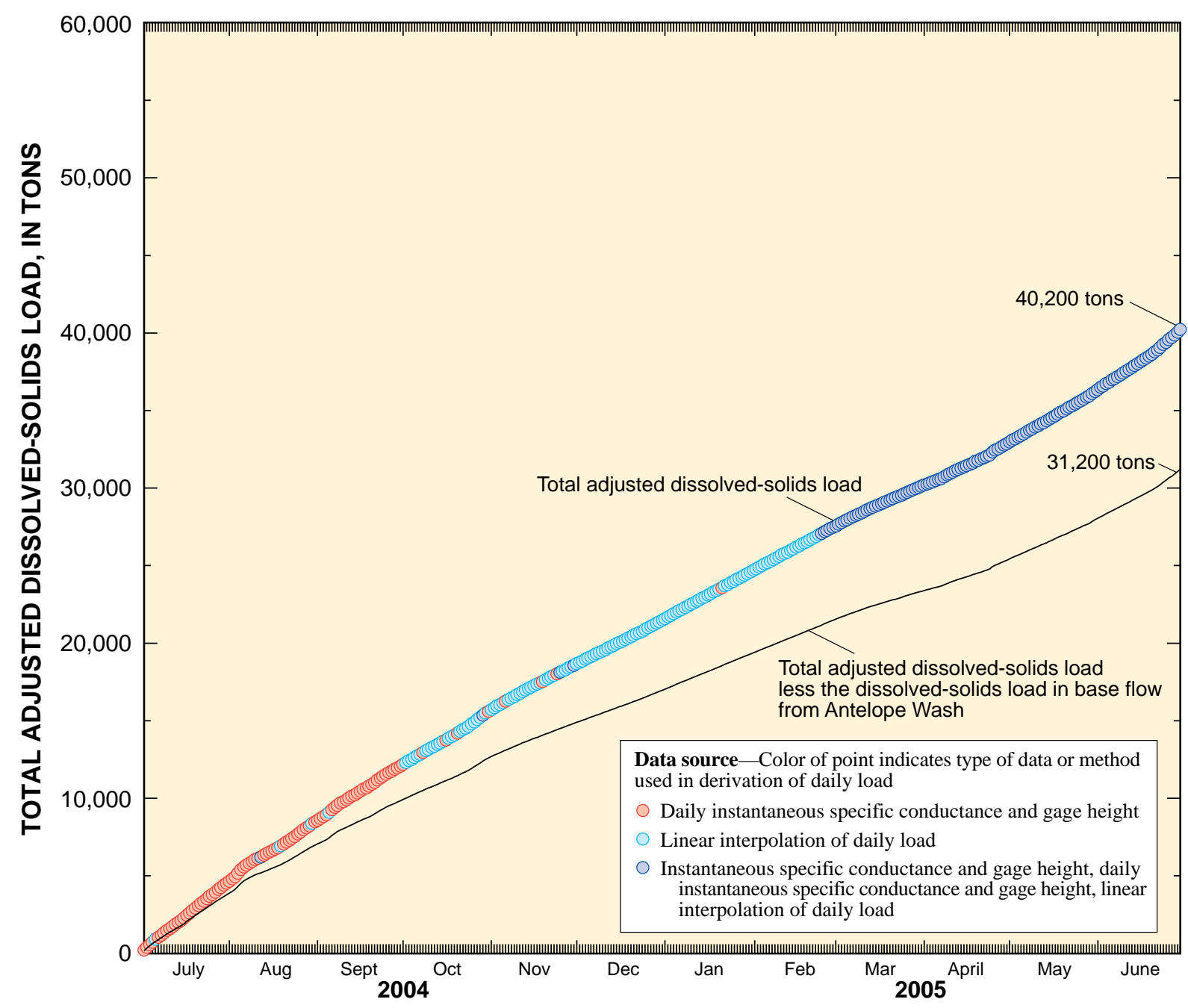

Figure 8. Cumulative total adjusted dissolved-solids load discharged from the study area near Manila, Utah, July 1, 2004 , through June 30,2005 . Symbol indicates type of data included in derivation of the daily total adjusted dissolved-solids load estimate.

tion in South Valley is much lower than in Lucerne Valley. The flow-weighted mean concentration of dissolved solids in applied irrigation water was $39 \mathrm{mg} / \mathrm{L}$ and the mean dissolvedsolids concentration in water collected near the mouth of the South Valley drain during this period was $1,660 \mathrm{mg} / \mathrm{L}$. The increase in dissolved solids, as a result of processes occurring along flow paths followed by deep percolation in South Valley, is $1,620 \mathrm{mg} / \mathrm{L}$ or 2.2 tons per acre-ft.

A water/salt budget that takes into consideration such factors as canal inflow and seepage, water consumption by crops and phreatophytes, tailwater runoff, and evaporation is a frequently applied method of determining the amount of dissolved-solids discharge associated with agricultural activities in an area. Determining a water/salt budget is beyond the scope of this report, but the salt-loading factor determined here should be useful for these calculations.

\section{Differentiation of Dissolved-Solids Sources}

Naturally occurring isotopes of strontium and boron in the water are a useful tool for differentiating salinity sources. The delta strontium- $87\left(\delta^{87} \mathrm{Sr}\right)$ value is a measure of the isotopic ratio of naturally occurring ${ }^{87} \mathrm{Sr}$ and ${ }^{86} \mathrm{Sr}$. Unlike other isotopes, $\mathrm{Sr}$ isotopes do not measurably fractionate in nature. Instead, $\delta^{87} \mathrm{Sr}$ values give insight into water-rock interaction processes. In similar lithologies, a water sample representing a shorter hydrologic flow path (irrigation return flow) will likely have a different isotopic signal than a water sample representing a longer hydrologic flow path (regional aquifer salinity source; Barbieri and Morotti, 2003). For example, in research conducted by Nimz and others (1992), shallow ground water contained positive $\delta^{87} \mathrm{Sr}$ values as a result of short-term waterrock interaction, and the deeper regional ground water contained negative $\delta^{87} \mathrm{Sr}$ values as a result of increased residence time for interaction with more chemically resistant mineral phases. Strontium isotopes have been used successfully to 
Table 8. Precipitation at Manila, Utah, and streamflow in Henrys Fork near Manila, Utah, July 2004 through June 2005

[ft $\mathrm{ft}^{3} / \mathrm{s}$, cubic feet per second]

\begin{tabular}{|c|c|c|c|c|}
\hline \multirow[b]{2}{*}{ Month } & \multicolumn{2}{|c|}{$\begin{array}{c}\text { Precipitation at Manila, } \\
\text { Utah }^{1}\end{array}$} & \multicolumn{2}{|c|}{$\begin{array}{c}\text { Streamflow in Henrys Fork } \\
\text { near Manila, Utah }{ }^{2}\end{array}$} \\
\hline & $\begin{array}{c}\text { Monthly } \\
\text { total, } \\
\text { in inches }\end{array}$ & $\begin{array}{c}\text { Departure } \\
\text { from } \\
\text { average }^{3}, \\
\text { in inches }\end{array}$ & $\begin{array}{c}\text { Monthly } \\
\text { mean, } \\
\text { in } \mathrm{ft}^{3} / \mathrm{s}\end{array}$ & $\begin{array}{c}\text { Departure } \\
\text { from aver- } \\
\text { age monthly } \\
\text { mean } \\
\text { in } \mathrm{ft}^{3} / \mathrm{s}\end{array}$ \\
\hline \multicolumn{5}{|c|}{2004} \\
\hline Jul & 0.81 & -0.15 & 15.9 & -74.3 \\
\hline Aug & .93 & .04 & 7.2 & -41.7 \\
\hline Sep & 1.05 & .18 & 5.3 & -27.7 \\
\hline Oct & 2.45 & 1.62 & 31 & -14.4 \\
\hline Nov & .76 & .23 & 65.1 & 10.4 \\
\hline Dec & .1 & -.22 & 76.3 & 28.3 \\
\hline \multicolumn{5}{|c|}{2005} \\
\hline Jan & .35 & .03 & 73.2 & 30.2 \\
\hline Feb & .08 & -.28 & 55.4 & 9.2 \\
\hline Mar & .35 & -.28 & 56.6 & -12.4 \\
\hline Apr & .87 & -.15 & 31.2 & -50.6 \\
\hline May & 1.04 & -.24 & 154 & 3 \\
\hline Jun & .72 & -.37 & 168 & -98 \\
\hline
\end{tabular}

${ }^{1}$ Data from Western Regional Climate Center (2005).

${ }^{2}$ Data from Watson and others (2005 and 2006).

${ }^{3}$ Average of monthly data, 1952-2005.

${ }^{4}$ Average of monthly data, 1929-2005.

differentiate salinity sources in water from southeastern Utah (Spangler and others, 1996; Naftz and others, 1997).

The second isotopic tool of interest for differentiating salinity sources is boron. The delta boron- $11\left(\delta^{11} \mathrm{~B}\right)$ value is a measure of the isotopic ratio of naturally occurring ${ }^{11} \mathrm{~B}$ and ${ }^{10} \mathrm{~B}$. Natural water has a wide range of $\delta^{11} \mathrm{~B}$ values ranging from -16 to +59 permil (Vengosh and others, 1994). Examples of values for several end-member waters include: -0.9 to +10.2 permil for non-marine sodium borate minerals; +2 to +12.9 permil for treated sewage effluent; +30 permil for uncontaminated ground water; -2.0 to +0.7 permil for nitrogen fertilizers; +7.2 to +11.2 permil for manure-based fertilizers; and +39 permil for seawater (Vengosh and others, 1994; Komor, 1997; Barth, 1998). Because of the application of fertilizers on irrigated lands, as well as other processes, it is likely that water from irrigation-return flow would have a distinctly different isotopic composition than other water sources in a particular area. The combination of both $\delta^{11} \mathrm{~B}$ and $\delta^{87} \mathrm{Sr}$ values in water can be a powerful dual isotopic source-identification technique that may differentiate salinity sources better than the use of each isotope independently.

Water samples were collected from selected sites in the study area and analyzed for boron, strontium, $\delta^{11} \mathrm{~B}$, and $\delta^{87} \mathrm{Sr}$ (table 10). Some water samples were collected from what might be considered an end member in a mixing model. For example, the water samples from sites SCC-1 and PC-1 represent the imported irrigation water. The water sample from spring SPG-1 (fig. 1) represents regional ground water that does not have an irrigation return-flow component. Water samples from drains don't likely represent an end member but a mixture of flow components that includes irrigation return flow and possibly regional ground water. Among these sample types there was a wide range in concentrations of strontium and boron as well as in the isotope ratios.

The variation of $\delta^{87} \mathrm{Sr}$ with strontium concentration indicates some general patterns that help to define a conceptual model of the processes affecting the concentration of strontium and the $\delta^{87} \mathrm{Sr}$ isotopic ratio in study-area waters (fig. 9). Water samples collected from canals (from sites SCC- 1 and PC-1) had relatively low concentrations of strontium (less than $3,000 \mu \mathrm{g} / \mathrm{L}$ ) and more positive (heavier) $\delta^{87} \mathrm{Sr}$ isotopic ratios (greater than 1 permil). Water samples collected from drains had strontium concentrations ranging from 3,350 to 7,380 $\mu \mathrm{g} / \mathrm{L}$ and lighter $\delta^{87} \mathrm{Sr}$ isotopic ratios. As irrigation water from the canals, which may be applied to fields in excess of crop consumptive needs, percolates through soils derived from the Mancos Shale, the $\delta^{87} \mathrm{Sr}$ isotopic ratio of that water approaches one that is typical of deep percolation from irrigation on Mancos Shale. In this case, that value is in the range of 0.21 to 0.69 permil. At the same time, strontium is being leached from Mancos Shale and concentrated by evapotranspiration so that the concentration of strontium in water samples collected from drains is much higher relative to that in water samples collected from canals. The water sample collected from site SPG-1, a small spring upgradient of the agricultural lands, had a negative $\delta^{87} \mathrm{Sr}$ isotope ratio and a relatively low strontium concentration. The strontium concentration and $\delta^{87} \mathrm{Sr}$ isotope ratio data collected during this study are insufficient to develop a complete mixing model; however, the distribution of the data in figure 9 indicates that there probably is no strong regional ground-water component affecting these constituents in water samples collected from drains.

Boron stable-isotope ratios do not vary systematically as do strontium ratios. Instead, values of $\delta^{11} \mathrm{~B}$ may more likely represent sources of the boron. Few distinctions in boron isotope values from the study area seem clear relative to reported ranges in the literature. However, the value of $\delta^{11} \mathrm{~B}$ in the sample collected from Antelope Wash falls in the range reported for hydrothermal fluids (fig. 10; see Vengosh and others, 1994; Komor, 1997; Barth, 1998). The boron concentration and $\delta^{11} \mathrm{~B}$ value for the water sample from Antelope Wash being distinctly different from water samples from other sites is further evidence that water in Antelope Wash may have a substantial component of regional ground-water flow from the Bridger aquifer.

The variation in strontium and boron concentrations and isotope ratios provide a means to distinguish end members within the study area. The isotope ratios potentially provide some information that may lead to distinguishing a regional component of mixing from irrigation return flow; however, the 
Table 9. Discharge and water-quality characteristics for selected water-quality monitoring sites used in the calculation of salt-loading factors for the study area near Manila, Utah

$\left[\mathrm{ft}^{3} / \mathrm{s}\right.$, cubic feet per second; ${ }^{\circ} \mathrm{C}$, degrees Celsius; $\mathrm{mg} / \mathrm{L}$, milligrams per liter; $<$, less than; —, no data]

\begin{tabular}{|c|c|c|c|c|}
\hline $\begin{array}{c}\text { Site } \\
\text { identifier } \\
\text { (see table 1) }\end{array}$ & $\begin{array}{l}\text { Site } \\
\text { type }\end{array}$ & Date & $\begin{array}{c}\text { Discharge, } \\
\text { in } \mathrm{ft}^{3} / \mathrm{s}\end{array}$ & $\begin{array}{c}\text { Dissolved- } \\
\text { solids } \\
\text { concentration } \\
\text { from residue } \\
\text { on evapora- } \\
\text { tion at } 180^{\circ} \mathrm{C} \text {, } \\
\text { in } \mathrm{mg} / \mathrm{L}\end{array}$ \\
\hline \multicolumn{5}{|c|}{ Lucerne Valley inflow } \\
\hline SCC-1 & canal & $07 / 01 / 04$ & 97 & 35 \\
\hline SCC-1 & canal & 08/10/04 & 60 & 39 \\
\hline SCC-1 & canal & $09 / 14 / 04$ & 34 & 58 \\
\hline SCC-1 & canal & $06 / 01 / 05$ & 126 & 37 \\
\hline PC-1 & canal & $06 / 29 / 04$ & 50 & 808 \\
\hline PC-1 & canal & 08/10/04 & 23 & 802 \\
\hline PC-1 & canal & $09 / 14 / 04$ & 24 & 1,210 \\
\hline PC-1 & canal & 06/01/05 & 41 & 265 \\
\hline \multicolumn{5}{|c|}{ Lucerne Valley outflow } \\
\hline BSD-2 & drain & $11 / 23 / 04$ & 3.5 & 4,850 \\
\hline BSD-2 & drain & $01 / 20 / 05$ & 2.9 & 4,840 \\
\hline BSD-2 & drain & $02 / 24 / 05$ & 3.4 & 5,940 \\
\hline BSD-2 & drain & $04 / 06 / 05$ & 2.2 & 4,970 \\
\hline $\mathrm{CC}-1$ & drain & $01 / 19 / 05$ & .6 & 4,070 \\
\hline $\mathrm{CC}-1$ & drain & $04 / 05 / 05$ & .2 & 3,910 \\
\hline DRN-1 & drain & $11 / 23 / 04$ & .1 & 3,740 \\
\hline DRN-1 & drain & $01 / 19 / 05$ & $<.1$ & 4,060 \\
\hline DRN-1 & drain & $04 / 05 / 05$ & .2 & 3,890 \\
\hline DRN-1A & drain & $11 / 23 / 04$ & .1 & 4,680 \\
\hline DRN-1A & drain & $01 / 19 / 05$ & $<.1$ & 4,200 \\
\hline DRN-1A & drain & $04 / 05 / 05$ & $<.1$ & 6,320 \\
\hline DRN-2 & drain & $11 / 23 / 04$ & .1 & 4,780 \\
\hline DRN-2 & drain & $01 / 19 / 05$ & .1 & 4,930 \\
\hline DRN-2 & drain & $02 / 25 / 05$ & .1 & 5,000 \\
\hline DRN-2 & drain & $04 / 06 / 05$ & .1 & 5,300 \\
\hline DRN-3 & drain & $11 / 23 / 04$ & .1 & 3,510 \\
\hline DRN-3 & drain & $01 / 20 / 05$ & $<.1$ & 3,320 \\
\hline DRN-3 & drain & $02 / 24 / 05$ & $<.1$ & 3,340 \\
\hline DRN-3 & drain & $04 / 06 / 05$ & .1 & 3,360 \\
\hline DRN-4 & drain & $11 / 23 / 04$ & $<.1$ & 3,090 \\
\hline DRN-4 & drain & $01 / 20 / 05$ & $<.1$ & 2,860 \\
\hline DRN-4 & drain & $02 / 24 / 05$ & $<.1$ & 1,760 \\
\hline DRN-5 & drain & $11 / 23 / 04$ & $<.1$ & 2,840 \\
\hline
\end{tabular}

Table 9. Discharge and water-quality characteristics for selected water-quality monitoring sites used in the calculation of salt-loading factors for the study area near Manila, Utah -Continued

\begin{tabular}{|c|c|c|c|c|}
\hline $\begin{array}{c}\text { Site } \\
\text { identifier } \\
\text { (see table 1) }\end{array}$ & $\begin{array}{l}\text { Site } \\
\text { type }\end{array}$ & Date & $\begin{array}{l}\text { Discharge, } \\
\text { in } \mathrm{ft}^{3} / \mathrm{s}\end{array}$ & $\begin{array}{c}\text { Dissolved- } \\
\text { solids } \\
\text { concentration } \\
\text { from residue } \\
\text { on evapora- } \\
\text { tion at } 180^{\circ} \mathrm{C} \text {, } \\
\text { in } \mathrm{mg} / \mathrm{L}\end{array}$ \\
\hline \multicolumn{5}{|c|}{ Lucerne Valley outflow-Continued } \\
\hline $\mathrm{PC}-2$ & drain & $11 / 23 / 04$ & .5 & 2,800 \\
\hline PC-2 & drain & $01 / 20 / 05$ & .3 & 2,740 \\
\hline $\mathrm{PC}-2$ & drain & $02 / 24 / 05$ & .1 & 2,840 \\
\hline PC-2 & drain & $04 / 06 / 05$ & .1 & 2,880 \\
\hline SP-3 & seep & $11 / 23 / 04$ & $<.1$ & 3,660 \\
\hline SP-1 & seep & $11 / 23 / 04$ & $<.1$ & 3,860 \\
\hline \multicolumn{5}{|c|}{ South Valley inflow } \\
\hline SCC-1 & canal & $05 / 27 / 04$ & - & 38 \\
\hline SCC-1 & canal & $07 / 01 / 04$ & - & 35 \\
\hline SCC-1 & canal & 08/10/04 & - & 39 \\
\hline SCC-1 & canal & 09/14/04 & - & 58 \\
\hline SCC-1 & canal & $06 / 01 / 05$ & - & 37 \\
\hline \multicolumn{5}{|c|}{ South Valley outflow } \\
\hline SV-2 & drain & $11 / 24 / 04$ & 2.1 & 1,460 \\
\hline SV-2 & drain & $01 / 20 / 05$ & 1.1 & 1,740 \\
\hline SV-1 & drain & $02 / 24 / 05$ & 1.4 & 1,980 \\
\hline SV-2 & drain & $04 / 06 / 05$ & .7 & 1,450 \\
\hline
\end{tabular}




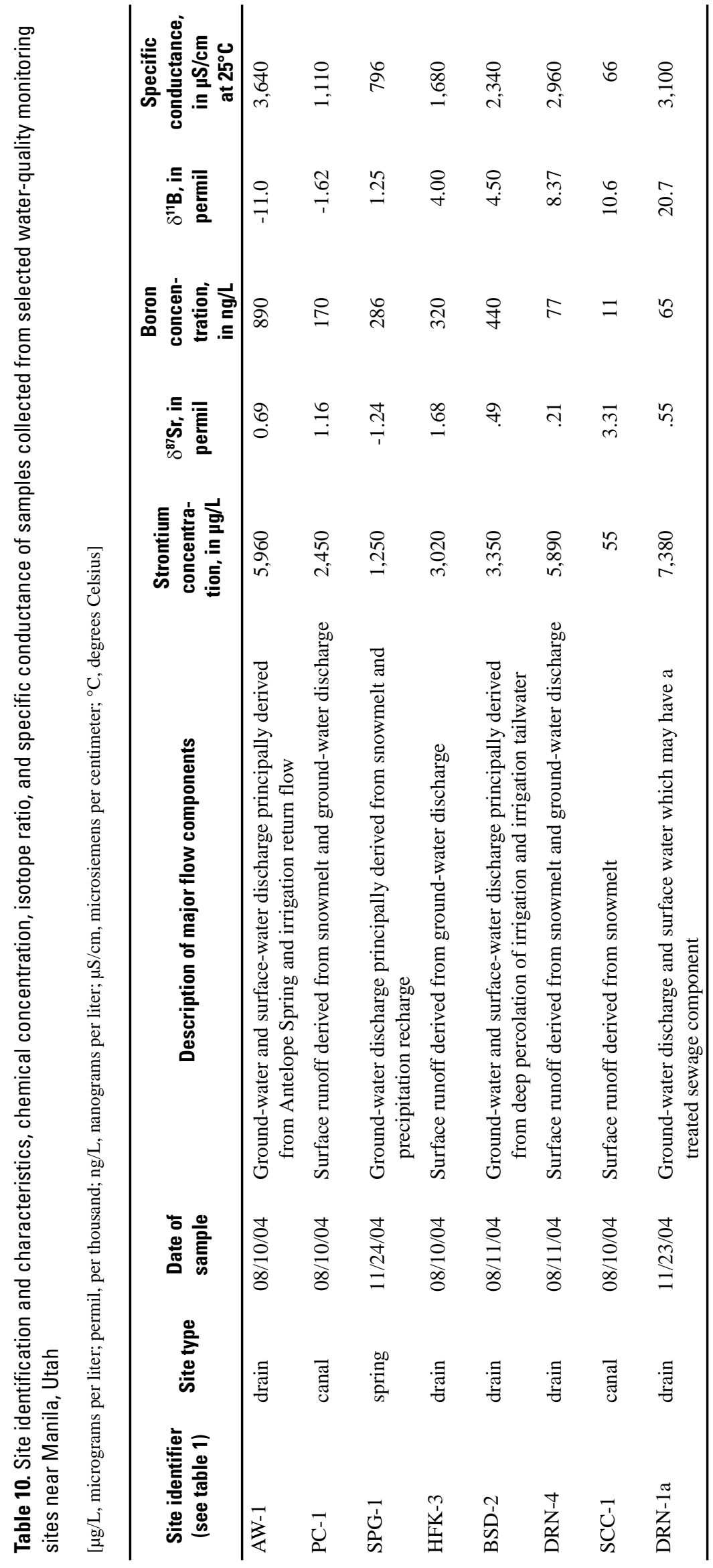




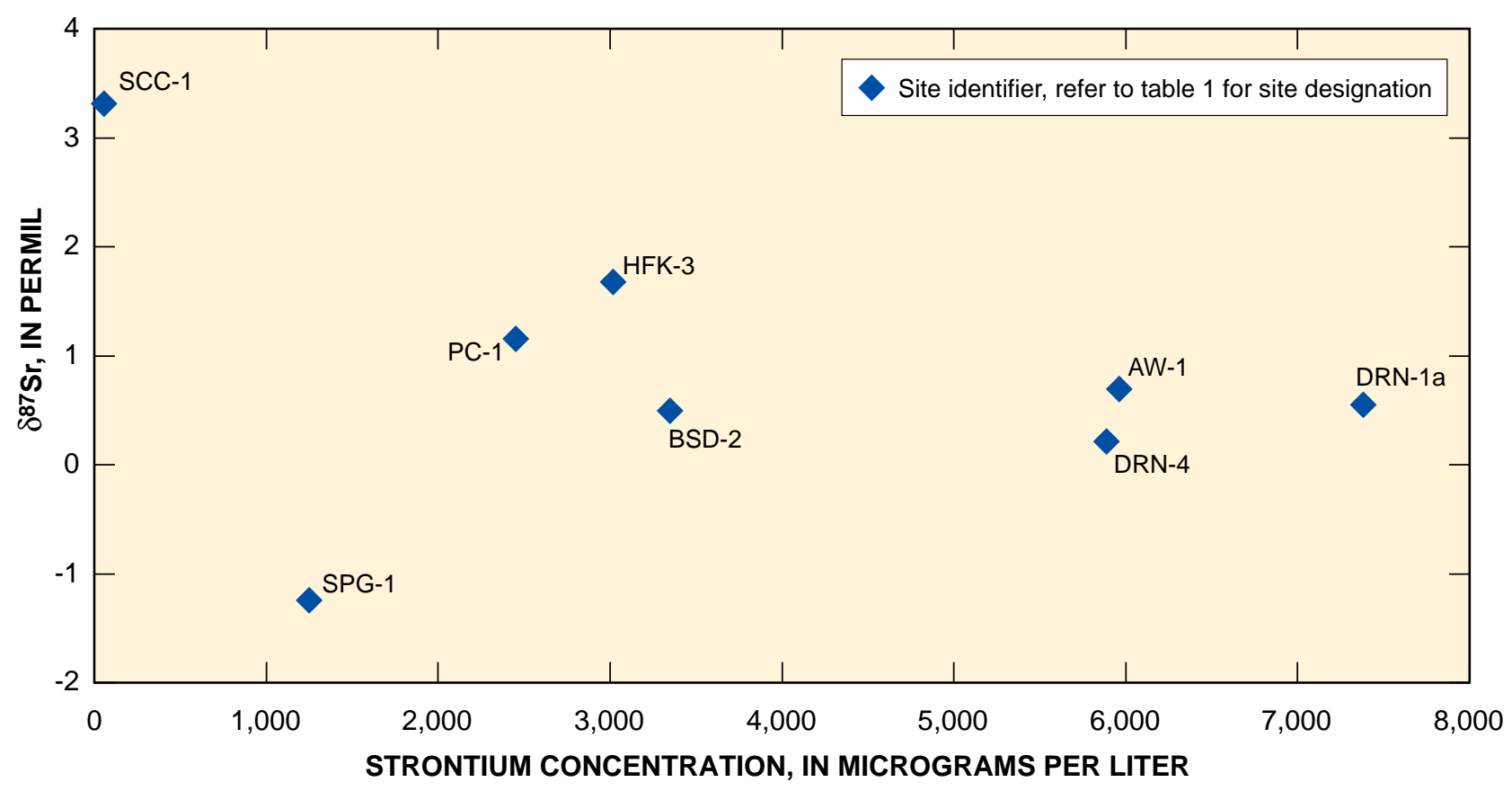

Figure 9. Variation of $\delta^{87} \mathrm{Sr}$ with strontium concentration in samples collected from selected sites near Manila, Utah.

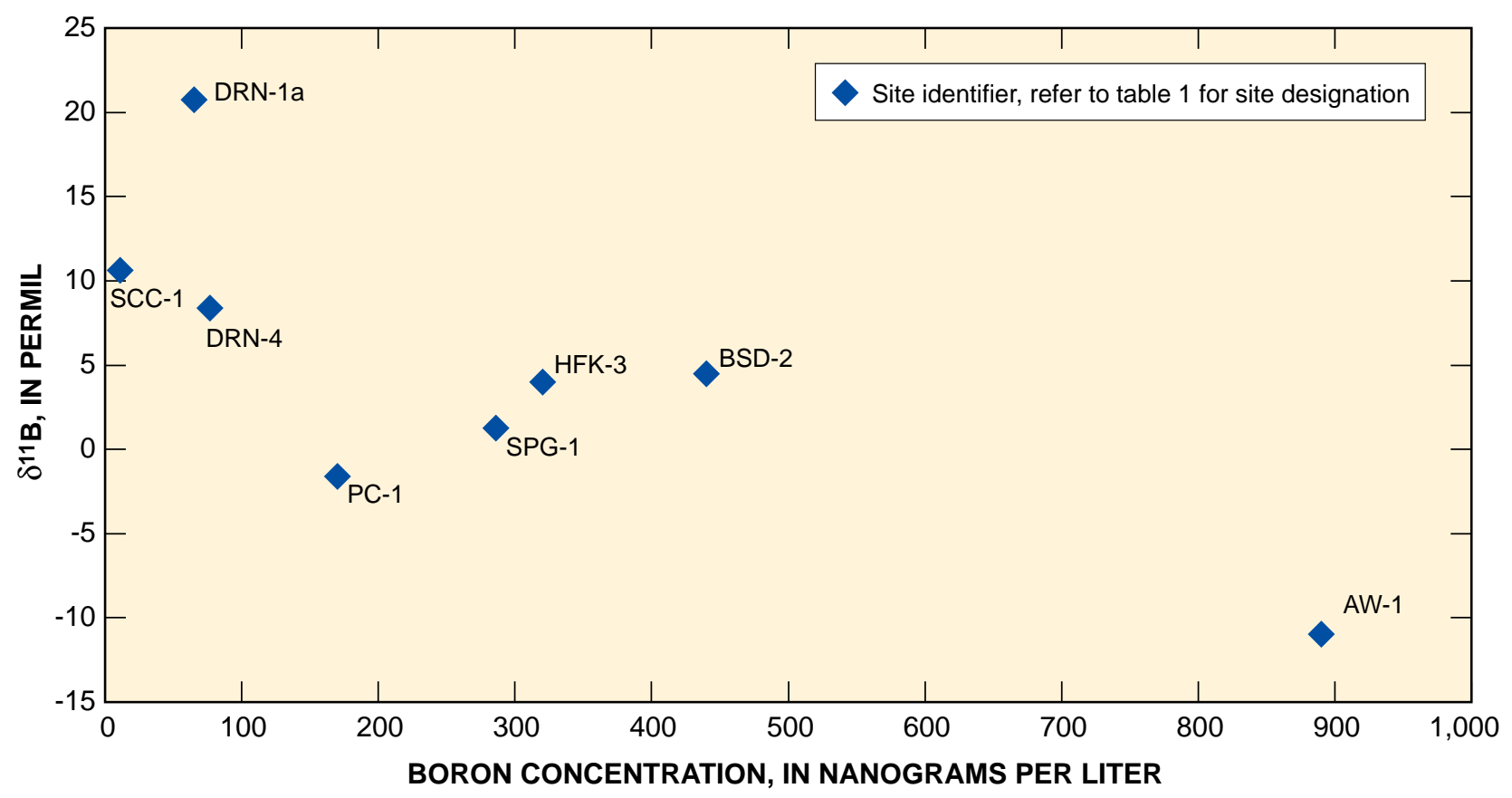

Figure 10. Variation of $\delta^{11} \mathrm{~B}$ with boron concentration in samples collected from selected sites near Manila, Utah 
results from isotope data collected during this study are inconclusive. Sampling spatially along drains as well as additional end-member sampling, such as water from shallow and deep wells, Antelope Springs, the Manila sewage-treatment ponds, and Henrys Fork upstream of the Antelope Wash inflow, could provide additional data that would help quantify the dissolved solids contributed to FGR from these components of flow.

\section{Summary}

Water users in the Upper Colorado River Basin consume water from the Colorado River and its tributaries, reducing the amount of water in the river that is suitable for domestic use and crop irrigation. At the same time, the application of water to agricultural land within the basin, in excess of crop needs, can increase the transport of dissolved solids to the river. The U.S. Department of Agriculture (USDA) is a partner in the Colorado River Salinity Control Program, directing offices of the Natural Resources Conservation Service (NRCS) in the Upper Colorado River Basin to make reductions, where possible, in the dissolved-solids load discharging to the Colorado River from agricultural lands. The agricultural lands near Manila, Utah, have been identified by the NRCS as areas contributing dissolved solids to Flaming Gorge Reservoir (FGR), in which the Green River - a tributary of the Colorado River - is impounded. This report documents the methods used in, and results of, an evaluation to determine the amount of dissolved solids contributed to FGR from Lucerne Valley, South Valley, Antelope Hollow, and a portion of Henrys Fork near Manila, Utah.

The major-ion composition of study area waters varies substantially. For example, much of the surface inflow to the study area is calcium bicarbonate type water and most of the outflow is calcium sulfate type water. Water discharged from drains and seeps near the FGR shoreline is generally more mineralized than water imported to the study area by Peoples and Sheep Creek Canals. In the study area, concentrations of dissolved solids ranged from 35 to $7,410 \mathrm{mg} / \mathrm{L}$. The dissolved-solids load in seeps and drains in the study area, which discharge to FGR, ranged from less than 0.1 to 157 tons/d. The most substantial source of dissolved-solids discharging from the study area to FGR was Birch Spring Draw. The mean dissolved-solids load near the mouth of Birch Spring Draw was 65 tons/d.

The estimated annual dissolved-solids load imported to the study area by Sheep Creek and Peoples Canals is 1,330 and 13,200 tons, respectively. The daily dissolved-solids load discharging to FGR from the study area, less the amount of dissolved solids imported by canals, for July 1, 2004, to June 30,2005 , ranged from 72 to 241 tons/d with a mean of 110 tons/d. The estimated annual dissolved-solids load discharging to FGR from the study area, less the amount of dissolved solids imported by canals, for the same period, was 40,200 tons; however, of this 40,200 tons of dissolved solids, about 9,000 tons discharging from Antelope Wash may be attributed to a regional source that is not associated with agricultural activities in the study area.

The difference in concentration between dissolved solids in water applied to fields in the study area for irrigation and ground water discharging to FGR is termed the dissolved-solids (salt) loading factor. This value is useful for estimating the amount of dissolved solids discharged to FGR that is associated with each acre-ft of deep percolation. The salt-loading factor is $3,670 \mathrm{mg} / \mathrm{L}$ or about 5.0 tons of dissolved solids per acre-ft of deep percolation in Lucerne Valley and 1,620 mg/L or 2.2 tons per acre-ft in South Valley.

Water samples from selected sites in the Manila area were collected and analyzed for boron, $\delta^{11} \mathrm{~B}$, strontium, and $\delta^{87} \mathrm{Sr}$. Water samples collected from canals had relatively low concentrations of strontium (less than $3,000 \mu \mathrm{g} / \mathrm{L}$ ) and more positive $\delta^{87} \mathrm{Sr}$ isotopic ratios (greater than 1 permil). Water samples collected from drains had strontium concentrations ranging from 3,350 to $7,380 \mu \mathrm{g} / \mathrm{L}$, and lighter $\delta^{87} \mathrm{Sr}$ isotopic ratios. The water sample from site SPG-1, a small spring upgradient of the agricultural lands, had a negative $\delta^{87} \mathrm{Sr}$ isotope ratio and a relatively low strontium concentration.

As irrigation water from the canals, which may be applied to fields in excess of crop consumptive needs, percolates through soils derived from Mancos Shale, it appears the $\delta^{87} \mathrm{Sr}$ isotopic ratio of that water approaches one that is typical of deep percolation from irrigation on Mancos Shale (0.21 to 0.69 permil). At the same time, strontium is being leached from Mancos Shale and concentrated by evapotranspiration so that the concentration of strontium in water samples collected from drains is much higher relative to that in water samples collected from canals.

The boron concentration and $\delta^{11} \mathrm{~B}$ value for the water sample collected from Antelope Wash was distinctly different from water samples collected from other sites. This provides some evidence that water in Antelope Wash may have a substantial component of regional ground-water flow.

\section{References Cited}

Barbieri, M., and Morotti, M., 2003, Hydrogeochemistry and strontium isotopes of spring and mineral waters from Monte Vulture volcano, Italy: Applied Geochemistry, v. 18, p. 117125 .

Barth, S., 1998, Application of boron isotopes for tracing sources of anthropogenic contamination in groundwater: Water Resources, v. 32, p. 685-690.

Buchanan, T.J., and Somers, W.P., 1969, Discharge measurements at gaging stations: U.S. Geological Survey Techniques of Water-Resources Investigations, book 3, chap. A8, $65 \mathrm{p}$. 
Fishman, M.J., and Friedman, L.C., 1989, Methods for determination of inorganic substances in water and fluvial sediments: U.S. Geological Survey Techniques of WaterResources Investigations, book 5, chap. A1, 545 p.

Hedlund, J.D., 1994, Salt primer - Water and salt budgets: Portland, Oregon, Soil Conservation Service, West National Technical Center, 60 p.

Hemphill, L.S., Water atlas of Utah, Class A pan evaporation for Utah, May - October, 1956-1970, accessed May 2005 at http://www.engineering.usu.edu/uwrl/atlas/ch3/index.html

Hintze, L.F., Willis, G.C., Laes, D.Y.M., Sprinkel, D.A., and Brown, K.D., 2000, Digital geologic map of Utah: Utah Geological Survey Map 179DM, scale 1:500,000

Johnson, M.W., Parson, R.E Stebbins, D.A, 1998, A history of Daggett County: A modern frontier: Salt Lake City, Utah, Utah State Historical Society [and] Daggett County Commission, $315 \mathrm{p}$.

Kennedy, E.J., 1983, Computation of continuous records of streamflow: U.S. Geological Survey Techniques of WaterResources Investigations, book 3, chap. A13, 53 p.

Koenig, K.J., 1960, Bridger Formation in the Bridger Basin, Wyoming, in McGookey, D.P., and Miller, D.N., Jr., eds., Overthrust belt of southwestern Wyoming and adjacent areas: Wyoming Geological Association, $15^{\text {th }}$ Annual Field Conference Guidebook, p. 195-209.

Komor, S.C., 1997, Boron contents and isotopic composition of hog manure, selected fertilizers, and water in Minnesota: Journal of Environmental Quality, v. 26, p. 1212- 1222.

Love, J.D., and Christiansen, A.C., 1985, Geologic map of Wyoming: U.S. Geological Survey Map, scale 1:500,000.

Mason, J.P., and Miller, K.A., 2004, Water resources of Sweetwater County, Wyoming: U.S. Geological Survey Scientific Investigations Report 2004-5214, 188 p.

Naftz, D.L., Peterman, Z.E., and Spangler, L.E., 1997, Using $\delta^{87} \mathrm{Sr}$ values to identify sources of salinity to a freshwater aquifer, Greater Aneth Oil Field, Utah, U.S.A.: Chemical Geology, v. 141, p. 195-209.

Nimz, G.J., Smith, D.K., Caffee, M.W., Finkel, R.C., Hudson, G.B., Borchers, J.W., and Nimz, K.P., 1992, Isotope characterization of hydrologic structure and chemical interaction between groundwater and granitic rock in the Wawona Basin, Yosemite National Park: Eos, Transaction, American Geophysical Union, v. 73, p. 170.
Radtke, D.B., Davis, J.B., and Wilde, F.D, eds., August 2005, Specific electrical conductance field measurement: U.S. Geological Survey Techniques of Water-Resources Investigations, book 9, chap. A6.3, accessed January 2006 at http://water.usgs.gov/ow q/FieldM a nual/C hapter6/6.3_contents.html

Schwarz, G.E., and Alexander, R.B, 1995, State Soil Geographic (STATSGO) data base for the conterminous United States: U.S. Geological Survey Open-File Report 95-449, digital map, scale 1:250,000, online version at http://water. usgs.gov/lookup/getspatial? ussoils

Spangler, L.E., Naftz, D.L., and Peterman, Z.E., 1996, Hydrology, chemical quality, and characterization of salinity in the Navajo aquifer in and near the Greater Aneth Oil Field, San Juan County, Utah: U.S. Geological Survey WaterResources Investigations Report 96-4155, 90 p.

U.S. Department of the Interior, 2003, Quality of water-Colorado River Basin: Bureau of Reclamation, Upper Colorado Region, Salt Lake City, Utah, Progress report no. 21, 83 p. plus appendix.

U.S. Geological Survey, 2006, National Land Cover Dataset, accessed January 2006 at http://landcover.usgs.gov/natllandcover.php

Vengosh, A., Heumann, K.G., Juraske, S., and Kasher, R., 1994, Boron isotope application for tracing sources of contamination in groundwater: Environmental Science and Technology, v. 28, p. 1968-1974.

Watson, K.R., Woodruff, R.E., Laidlaw, G.A., Clark, M.L., and Miller, K.A., 2005, Water resources data, Wyoming, water year 2004; Volume 1. Surface water: U.S. Geological Survey Water-Data Report WY-04-1, 591 p.

Watson, K.R., Woodruff, R.E., Laidlaw, G.A., Clark, M.L., and Miller, K.A., 2006, Water resources data, Wyoming, water year 2005; Volume 1. Surface water: U.S. Geological Survey Water-Data Report WY-05-1, 592 p.

Webb, W.E., Radtke, D.B., and Iwatsubo, R.T., September 1999, Surface-water sampling: collection methods at flowing-water and still-water sites: U.S. Geological Survey Techniques of Water-Resources Investigations, book 9, chap. A4.1, accessed January 2006 at http://water.usgs. gov/owq/FieldM anual/chapter4/html/4.1_contents.html

Western Regional Climate Center, 2005, Period of record monthly climate summary, Manila, Utah: accessed October 14, 2005, at http://www.wrcc.dri.edu/cgi-bin/cliM AIN. pl? utmani 
Table 2. Instantaneous discharge and properties of water samples collected from water-quality monitoring sites near Manila, Utah $\left[\mathrm{ft} / \mathrm{s}\right.$, cubic feet per second; $\mu \mathrm{S} / \mathrm{cm}$, microsiemens per centimeter; ${ }^{\circ} \mathrm{C}$, degrees Celsius; $\mathrm{mg} / \mathrm{L}$, milligrams per liter; ROE, residue on evaporation at $180{ }^{\circ} \mathrm{C} ;-$, no data; e, estimated; <, less than]

\begin{tabular}{|c|c|c|c|c|c|c|c|c|}
\hline $\begin{array}{c}\text { Site } \\
\text { identifier } \\
\text { (see table 1) }\end{array}$ & $\begin{array}{l}\text { Site } \\
\text { type }\end{array}$ & $\begin{array}{c}\text { Sample } \\
\text { date }\end{array}$ & $\begin{array}{c}\text { Sample } \\
\text { time }\end{array}$ & $\begin{array}{c}\text { Discharge, } \\
\text { instanta- } \\
\text { neous } \\
\left(\mathrm{ft}^{3} / \mathrm{s}\right)\end{array}$ & $\begin{array}{l}\text { pH, water, } \\
\text { unfiltered, } \\
\text { laboratory } \\
\text { (standard } \\
\text { units) }\end{array}$ & $\begin{array}{c}\text { Specific } \\
\text { conductance, } \\
\text { water, } \\
\text { unfiltered, } \\
\text { laboratory } \\
(\mu \mathrm{S} / \mathrm{cm} \\
\left.\text { at } 25^{\circ} \mathrm{C}\right)\end{array}$ & $\begin{array}{c}\text { Specific } \\
\text { conductance, } \\
\text { water, } \\
\text { field, } \\
\text { unfiltered } \\
(\mu \mathrm{S} / \mathrm{cm} \\
\left.\text { at } 25^{\circ} \mathrm{C}\right)\end{array}$ & $\begin{array}{c}\text { Temper- } \\
\text { ature, } \\
\text { water } \\
\left({ }^{\circ} \mathrm{C}\right)\end{array}$ \\
\hline \multirow[t]{8}{*}{ HFK-3 } & stream & $08 / 10 / 04$ & 1700 & 4.3 & - & - & 1,680 & 24.3 \\
\hline & & $09 / 14 / 04$ & 1840 & 5.5 & 7.9 & 1,730 & 1,850 & 12.5 \\
\hline & & $10 / 26 / 04$ & 1750 & 46 & - & - & 1,230 & 6.9 \\
\hline & & $11 / 22 / 04$ & 1635 & 42 & - & - & 1,240 & - \\
\hline & & 01/19/05 & 1530 & 68 & - & - & 945 & .5 \\
\hline & & $02 / 25 / 05$ & 0900 & 30 & - & - & 977 & .1 \\
\hline & & $04 / 05 / 05$ & 1710 & 58 & - & - & 880 & 11.1 \\
\hline & & 06/01/05 & 1250 & e219 & - & - & 444 & 12.9 \\
\hline \multirow[t]{6}{*}{ HFK-1 } & stream & 09/14/04 & 1600 & e. 4 & - & - & 1,540 & 15.9 \\
\hline & & $10 / 26 / 04$ & 1520 & 40 & - & - & 1,070 & 10.1 \\
\hline & & $11 / 22 / 04$ & 1520 & 47 & - & - & 1,190 & 1.5 \\
\hline & & 01/19/05 & 1240 & 64 & - & - & 864 & - \\
\hline & & $02 / 25 / 05$ & 0710 & 29 & - & - & 918 & 2.3 \\
\hline & & $04 / 05 / 05$ & 1400 & 57 & - & - & 824 & 8.8 \\
\hline \multirow[t]{7}{*}{ SCC-1 } & canal & $05 / 27 / 04$ & 1300 & e100 & - & - & 62 & 10.9 \\
\hline & & 07/01/04 & 1225 & 97 & 7.5 & 64 & 60 & 13.5 \\
\hline & & 08/10/04 & 1125 & 60 & 7.2 & 63 & 66 & 15.8 \\
\hline & & 09/14/04 & 1250 & 34 & - & - & 90 & 15.0 \\
\hline & & $10 / 26 / 04$ & 1140 & .22 & - & - & 1,070 & 4.6 \\
\hline & & $04 / 05 / 05$ & 1130 & e. 1 & - & - & 1,930 & 7.7 \\
\hline & & 06/01/05 & 1750 & 126 & - & - & 61 & 9.1 \\
\hline \multirow[t]{8}{*}{ PC-1 } & canal & 06/29/04 & 1400 & 50 & 8 & 1,080 & 1,130 & 17.6 \\
\hline & & $07 / 22 / 04$ & 0900 & 40 & - & - & 1,100 & 16.5 \\
\hline & & 08/10/04 & 1330 & 23 & - & - & 1,110 & 21.0 \\
\hline & & 09/14/04 & 1430 & 24 & 8 & 1,480 & 1,540 & 15.5 \\
\hline & & $10 / 26 / 04$ & 1435 & 24 & - & - & 1,080 & 10.0 \\
\hline & & $11 / 22 / 04$ & 1445 & 1.6 & - & - & 1,210 & 1.4 \\
\hline & & 01/19/05 & 1315 & .01 & - & - & 864 & - \\
\hline & & 06/01/05 & 0840 & 41 & 7.9 & 362 & 390 & 11.4 \\
\hline \multirow[t]{6}{*}{ DRN-1 } & drain & 06/29/04 & 1635 & 2.7 & 8.1 & 2,290 & 2,400 & 17.6 \\
\hline & & 08/11/04 & 1650 & .25 & - & - & 2,910 & 20.5 \\
\hline & & 09/15/04 & 1800 & .03 & - & - & 3,870 & 12.5 \\
\hline & & $10 / 27 / 04$ & 1535 & .11 & - & - & 4,340 & 9.7 \\
\hline & & $11 / 23 / 04$ & 1500 & .1 & - & - & 3,800 & .3 \\
\hline & & 01/19/05 & 1610 & $<.01$ & - & - & 4,320 & .3 \\
\hline
\end{tabular}


Table 2. Instantaneous discharge and properties of water samples collected from water-quality monitoring sites near Manila, Utah-Continued

\begin{tabular}{|c|c|c|c|c|c|c|c|}
\hline $\begin{array}{c}\text { Site } \\
\text { identifier } \\
\text { (see table 1) }\end{array}$ & $\begin{array}{l}\text { Hardness, } \\
\text { water } \\
\text { (mg/L as } \\
\mathrm{CaCO}_{3} \text { ) }\end{array}$ & $\begin{array}{c}\text { Alkalinity, } \\
\text { water, filtered, } \\
\text { incremental } \\
\text { titration, lab } \\
(\mathbf{m g} / \mathbf{L})\end{array}$ & $\begin{array}{c}\text { Dissolved- } \\
\text { solids } \\
\text { concentration, } \\
\text { sum of } \\
\text { constituents, } \\
\text { water, } \\
\text { filtered } \\
\text { (mg/L) } \\
\end{array}$ & $\begin{array}{l}\text { Dissolved- } \\
\text { solids } \\
\text { concentration, } \\
\text { ROE, water, } \\
\text { filtered } \\
\text { (mg/L) }\end{array}$ & $\begin{array}{c}\mathrm{ROE} / \\
\text { Specific- } \\
\text { conductance } \\
\text { ratio }\end{array}$ & $\begin{array}{c}\text { Dissolved- } \\
\text { solids } \\
\text { concentration } \\
\text { from ROE/ } \\
\text { Specific- } \\
\text { conductance } \\
\text { ratio } \\
\text { (mg/L) } \\
\end{array}$ & $\begin{array}{l}\text { Dissolved- } \\
\text { solids } \\
\text { load } \\
\text { (tons } \\
\text { per day) }\end{array}$ \\
\hline \multirow[t]{8}{*}{ HFK-3 } & - & - & - & 1,520 & 0.90 & 1,520 & 17.6 \\
\hline & 930 & 242 & 1,360 & 1,470 & .79 & 1,470 & 21.8 \\
\hline & - & - & - & - & ${ }^{1} .82$ & 1,010 & 125 \\
\hline & - & - & - & 955 & .77 & 955 & 108 \\
\hline & - & - & - & - & ${ }^{1} .82$ & 775 & 142 \\
\hline & - & - & - & - & ${ }^{1} .82$ & 801 & 64.8 \\
\hline & - & - & - & - & ${ }^{1} .82$ & 722 & 113 \\
\hline & - & - & - & - & ${ }^{1} .82$ & 364 & e215 \\
\hline \multirow[t]{6}{*}{ HFK-1 } & - & - & - & - & ${ }^{1} .73$ & 1,120 & e1.21 \\
\hline & - & - & - & - & ${ }^{1} .73$ & 781 & 84.3 \\
\hline & - & - & - & - & ${ }^{1} .73$ & 869 & 110 \\
\hline & - & - & - & - & ${ }^{1} .73$ & 631 & 109 \\
\hline & - & - & - & - & ${ }^{1} .73$ & 670 & 52.4 \\
\hline & - & - & - & - & ${ }^{1} .73$ & 602 & 92.5 \\
\hline \multirow[t]{7}{*}{ SCC-1 } & - & - & - & - & ${ }^{1} .61$ & 38 & e10.2 \\
\hline & 25 & 16 & 32 & 35 & .58 & 35 & 9.16 \\
\hline & 26 & 26 & 38 & 39 & .59 & 39 & 6.31 \\
\hline & - & - & - & 58 & .64 & 58 & 5.32 \\
\hline & - & - & - & - & ${ }^{1} .72$ & 770 & .46 \\
\hline & - & - & - & - & ${ }^{1} .72$ & 1,390 & e. 37 \\
\hline & - & - & - & - & ${ }^{1} .61$ & 37 & 12.6 \\
\hline \multirow[t]{8}{*}{ PC-1 } & 600 & 255 & 802 & 808 & .72 & 808 & 109 \\
\hline & - & - & - & & ${ }^{1} .73$ & 803 & 86.6 \\
\hline & - & - & - & 802 & .72 & 802 & 49.7 \\
\hline & 770 & 189 & 1,110 & 1,210 & .79 & 1,210 & 78.3 \\
\hline & - & - & - & & ${ }^{1} .73$ & 788 & 51.0 \\
\hline & - & - & - & 904 & .75 & 904 & 3.90 \\
\hline & - & - & - & & ${ }^{1} .73$ & 631 & $<.02$ \\
\hline & 180 & 120 & 233 & 265 & .68 & 265 & 29.3 \\
\hline \multirow[t]{6}{*}{ DRN-1 } & 1,200 & 344 & 1,890 & 2,070 & .86 & 2,070 & 15.1 \\
\hline & - & - & - & 2,710 & .93 & 2,710 & 1.83 \\
\hline & - & - & - & 3,800 & .98 & 3,800 & .31 \\
\hline & - & - & - & - & ${ }^{1} .94$ & 4,080 & 1.21 \\
\hline & - & - & - & 3,740 & .98 & 3,740 & 1.01 \\
\hline & - & - & - & - & ${ }^{1} .94$ & 4,060 & ${ }^{1} .11$ \\
\hline
\end{tabular}


Table 2. Instantaneous discharge and properties of water samples collected from water-quality monitoring sites near Manila, Utah -Continued

\begin{tabular}{|c|c|c|c|c|c|c|c|}
\hline \multirow{2}{*}{ DRN-1-Continued } & $04 / 24 / 05$ & 1700 & .13 & - & - & 7,880 & 1.4 \\
\hline & $06 / 01 / 05$ & 1240 & e.05 & - & - & 3,740 & 13.9 \\
\hline \multirow[t]{4}{*}{ DRN-1a } & 08/11/04 & 1640 & .27 & - & - & 3,100 & 23.6 \\
\hline & $09 / 15 / 04$ & 1810 & .09 & - & - & 3,630 & 18.0 \\
\hline & $04 / 05 / 05$ & 1545 & .02 & - & - & 6,800 & 10.7 \\
\hline & 06/01/05 & 1220 & .2 & 7.8 & 4,190 & 4,350 & 14.1 \\
\hline \multirow[t]{6}{*}{ DRN-2 } & $06 / 29 / 04$ & 1740 & 5.8 & 8 & 2,100 & 2,170 & 16.9 \\
\hline & 08/11/04 & 1540 & 1.7 & - & - & 2,710 & 20.6 \\
\hline & $09 / 15 / 04$ & 1700 & .57 & 7.8 & 3,300 & 3,240 & 14.5 \\
\hline & $10 / 27 / 04$ & 1443 & .2 & - & - & 5,100 & 9.2 \\
\hline & $11 / 23 / 04$ & 1410 & .12 & - & - & 5,140 & 4.8 \\
\hline & $01 / 19 / 05$ & 1700 & .06 & - & - & 5,540 & 3.7 \\
\hline \multirow{7}{*}{ DRN-3 } & $09 / 15 / 04$ & 1120 & 1.7 & - & - & 1,970 & 9.5 \\
\hline & $10 / 27 / 04$ & 1140 & .31 & - & - & 2,850 & 7.3 \\
\hline & $11 / 23 / 04$ & 1030 & .05 & - & - & 3,650 & .5 \\
\hline & $01 / 20 / 05$ & 1220 & $<.01$ & - & - & 3,690 & .1 \\
\hline & $02 / 24 / 05$ & 1010 & e.01 & - & - & 3,710 & 5.5 \\
\hline & $04 / 06 / 05$ & 1010 & e.05 & - & - & 3,730 & 4.0 \\
\hline & $06 / 01 / 05$ & 1500 & .01 & - & - & 3,960 & 20.3 \\
\hline \multirow[t]{7}{*}{ DRN-4 } & $06 / 30 / 04$ & 1100 & .33 & - & - & 3,330 & 18.7 \\
\hline & $08 / 11 / 04$ & 1220 & $<.01$ & - & - & 2,960 & 19.7 \\
\hline & $09 / 15 / 04$ & 1245 & .08 & - & - & 2,460 & - \\
\hline & $10 / 27 / 04$ & 1240 & e. 3 & - & - & 3,040 & 10.1 \\
\hline & $11 / 23 / 04$ & 1100 & .02 & - & - & 3,220 & 3.4 \\
\hline & $01 / 20 / 05$ & 1240 & $<.01$ & - & - & 3,250 & 5.4 \\
\hline & $02 / 24 / 05$ & 1023 & $<.01$ & - & - & 2,000 & 3.5 \\
\hline
\end{tabular}


Table 2. Instantaneous discharge and properties of water samples collected from water-quality monitoring sites near Manila, Utah-Continued

\begin{tabular}{|c|c|c|c|c|c|c|c|}
\hline $\begin{array}{c}\text { Site } \\
\text { identifier } \\
\text { (see table 1) }\end{array}$ & $\begin{array}{l}\text { Hardness, } \\
\text { water } \\
\text { (mg/L as } \\
\mathrm{CaCO}_{3} \text { ) }\end{array}$ & $\begin{array}{c}\text { Alkalinity, } \\
\text { water, filtered, } \\
\text { incremental } \\
\text { titration, lab } \\
(\mathbf{m g} / \mathbf{L})\end{array}$ & $\begin{array}{c}\text { Dissolved- } \\
\text { solids } \\
\text { concentration, } \\
\text { sum of } \\
\text { constituents, } \\
\text { water, } \\
\text { filtered } \\
\text { (mg/L) } \\
\end{array}$ & $\begin{array}{l}\text { Dissolved- } \\
\text { solids } \\
\text { concentration, } \\
\text { ROE, water, } \\
\text { filtered } \\
\text { (mg/L) }\end{array}$ & $\begin{array}{c}\mathrm{ROE} / \\
\text { Specific- } \\
\text { conductance } \\
\text { ratio }\end{array}$ & $\begin{array}{c}\text { Dissolved- } \\
\text { solids } \\
\text { concentration } \\
\text { from ROE/ } \\
\text { Specific- } \\
\text { conductance } \\
\text { ratio } \\
\text { (mg/L) } \\
\end{array}$ & $\begin{array}{l}\text { Dissolved- } \\
\text { solids } \\
\text { load } \\
\text { (tons } \\
\text { per day) }\end{array}$ \\
\hline \multirow[t]{3}{*}{ DRN-1 } & - & - & - & - & ${ }^{1} .94$ & 3,890 & e2.10 \\
\hline & - & - & - & - & ${ }^{1} .94$ & 7,410 & 2.60 \\
\hline & - & - & - & - & ${ }^{1} .94$ & 3,520 & e. 47 \\
\hline \multirow[t]{7}{*}{ DRN-1a } & - & - & - & 2,820 & .91 & 2,820 & 2.05 \\
\hline & - & - & - & 3,480 & .96 & 3,480 & .84 \\
\hline & - & - & - & - & ${ }^{1} .93$ & 4,040 & 1.20 \\
\hline & 2,200 & 350 & 4,310 & 4,680 & .95 & 4,680 & .88 \\
\hline & - & - & - & - & ${ }^{1} .93$ & 4,200 & .23 \\
\hline & - & - & - & - & ${ }^{1} .93$ & 6,320 & .34 \\
\hline & 1,700 & 347 & 3,480 & 3,840 & .88 & 3,840 & 2.07 \\
\hline \multirow[t]{9}{*}{ DRN-2 } & 1,000 & 339 & 1,660 & 1,830 & .84 & 1,830 & 28.6 \\
\hline & - & - & - & 2,420 & .89 & 2,420 & 11.1 \\
\hline & 1,600 & 310 & 2,730 & 3,080 & .95 & 3,080 & 4.73 \\
\hline & - & - & - & - & ${ }^{1} .89$ & 4,540 & 2.45 \\
\hline & - & - & - & 4,780 & .93 & 4,780 & 1.55 \\
\hline & - & - & - & - & ${ }^{1} .89$ & 4,930 & .80 \\
\hline & - & - & - & - & ${ }^{1} .89$ & 5,000 & .94 \\
\hline & - & - & - & - & ${ }^{1} .89$ & 5,300 & 1.00 \\
\hline & 1,200 & 292 & 2,310 & 2,610 & .85 & 2,610 & 11.3 \\
\hline \multirow[t]{9}{*}{ DRN-3 } & - & - & - & 1,720 & .83 & 1,720 & 8.81 \\
\hline & - & - & - & 2,630 & .93 & 2,630 & .71 \\
\hline & - & - & - & 1,700 & .86 & 1,700 & 7.79 \\
\hline & - & - & - & - & ${ }^{1} .90$ & 2,560 & 2.14 \\
\hline & - & - & - & 3,510 & .96 & 3,510 & .47 \\
\hline & - & - & - & - & ${ }^{1} .90$ & 3,320 & $<.09$ \\
\hline & - & - & - & - & ${ }^{1} .90$ & 3,340 & e. 09 \\
\hline & - & - & - & - & ${ }^{1} .90$ & 3,360 & e. 45 \\
\hline & - & - & - & - & ${ }^{1} .90$ & 3,560 & $<.10$ \\
\hline \multirow[t]{7}{*}{ DRN-4 } & - & - & - & 3,050 & .92 & 3,050 & 2.71 \\
\hline & - & - & - & 2,730 & .92 & 2,730 & $<.07$ \\
\hline & - & - & - & - & ${ }^{1} .88$ & 2,160 & .47 \\
\hline & - & - & - & - & ${ }^{1} .88$ & 2,680 & e2.16 \\
\hline & - & - & - & 3,090 & .96 & 3,090 & .17 \\
\hline & - & - & - & - & ${ }^{1} .88$ & 2,860 & $<.08$ \\
\hline & - & - & - & - & ${ }^{1} .88$ & 1,760 & $<.05$ \\
\hline
\end{tabular}


Table 2. Instantaneous discharge and properties of water samples collected from water-quality monitoring sites near Manila, Utah -Continued

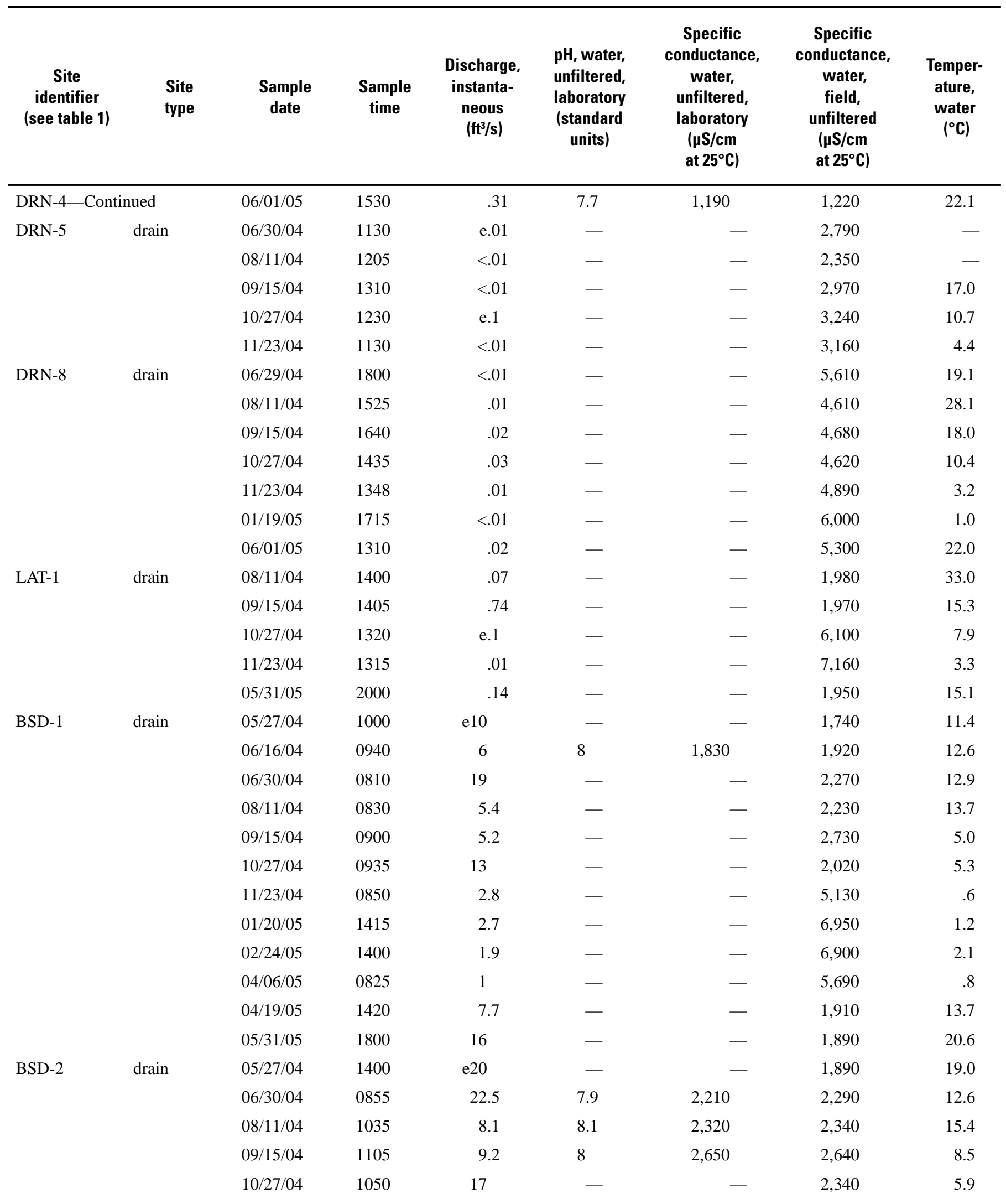


Table 2. Instantaneous discharge and properties of water samples collected from water-quality monitoring sites near Manila, Utah-Continued

\begin{tabular}{|c|c|c|c|c|c|c|c|}
\hline $\begin{array}{c}\text { Site } \\
\text { identifier } \\
\text { (see table 1) }\end{array}$ & $\begin{array}{c}\text { Hardness, } \\
\text { water } \\
(\mathrm{mg} / \mathrm{L} \text { as } \\
\left.\mathrm{CaCO}_{3}\right)\end{array}$ & $\begin{array}{l}\text { Alkalinity, } \\
\text { water, filtered, } \\
\text { incremental } \\
\text { titration, lab } \\
(\mathrm{mg} / \mathrm{L})\end{array}$ & $\begin{array}{c}\text { Dissolved- } \\
\text { solids } \\
\text { concentration, } \\
\text { sum of } \\
\text { constituents, } \\
\text { water, } \\
\text { filtered } \\
\text { (mg/L) }\end{array}$ & $\begin{array}{l}\text { Dissolved- } \\
\text { solids } \\
\text { concentration, } \\
\text { ROE, water, } \\
\text { filtered } \\
\text { (mg/L) }\end{array}$ & $\begin{array}{c}\mathrm{ROE} / \\
\text { Specific- } \\
\text { conductance } \\
\text { ratio }\end{array}$ & $\begin{array}{c}\text { Dissolved- } \\
\text { solids } \\
\text { concentration } \\
\text { from ROE/ } \\
\text { Specific- } \\
\text { conductance } \\
\text { ratio } \\
\text { (mg/L) }\end{array}$ & $\begin{array}{l}\text { Dissolved- } \\
\text { solids } \\
\text { load } \\
\text { (tons } \\
\text { per day) }\end{array}$ \\
\hline DRN-4 & 480 & 172 & 822 & 900 & .74 & 900 & .75 \\
\hline \multirow[t]{5}{*}{ DRN-5 } & - & - & - & - & ${ }^{1} .90$ & 2,510 & e. 07 \\
\hline & - & - & - & - & ${ }^{1} .90$ & 2,120 & $<.06$ \\
\hline & - & - & - & - & ${ }^{1} .90$ & 2,670 & $<.07$ \\
\hline & - & - & - & - & ${ }^{1} .90$ & 2,920 & e.79 \\
\hline & - & - & - & - & ${ }^{1} .90$ & 2,840 & $<.08$ \\
\hline \multirow[t]{7}{*}{ DRN-8 } & - & - & - & & ${ }^{1} .96$ & 5,390 & .15 \\
\hline & - & - & - & 4,360 & .95 & 4,360 & $<.12$ \\
\hline & - & - & - & 4,500 & .96 & 4,500 & .24 \\
\hline & - & - & - & - & ${ }^{1} .96$ & 4,440 & .36 \\
\hline & - & - & - & - & ${ }^{1} .96$ & 4,690 & .13 \\
\hline & - & - & - & - & ${ }^{1} .96$ & 5,760 & $<.16$ \\
\hline & - & - & - & - & ${ }^{1} .96$ & 5,090 & .27 \\
\hline \multirow[t]{5}{*}{ LAT-1 } & - & - & - & 1,630 & .82 & 1,630 & .31 \\
\hline & - & - & - & - & ${ }^{1} .82$ & 1,620 & 3.22 \\
\hline & - & - & - & - & ${ }^{1} .82$ & 5,000 & e1.35 \\
\hline & - & - & - & - & ${ }^{1} .82$ & 5,870 & .16 \\
\hline & - & - & - & - & ${ }^{1} .82$ & 1,600 & .60 \\
\hline \multirow[t]{12}{*}{ BSD-1 } & - & - & - & - & ${ }^{1} .81$ & 1,410 & e38.0 \\
\hline & 700 & 228 & 1,340 & 1,450 & .76 & 1,450 & 23.5 \\
\hline & - & - & - & 1,850 & .81 & 1,850 & 94.8 \\
\hline & - & - & - & 1,830 & .82 & 1,830 & 26.7 \\
\hline & - & - & - & 2,420 & .89 & 2,420 & 33.9 \\
\hline & - & - & - & - & ${ }^{1} .88$ & 1,780 & 62.3 \\
\hline & - & - & - & 4,440 & .87 & 4,440 & 33.5 \\
\hline & - & - & - & - & ${ }^{1} .81$ & 5,630 & 41.0 \\
\hline & - & - & - & - & ${ }^{1} .81$ & 5,590 & 28.6 \\
\hline & - & - & - & - & ${ }^{1} .81$ & 4,610 & 12.4 \\
\hline & - & - & - & - & ${ }^{1} .81$ & 1,550 & 32.1 \\
\hline & - & - & - & 1,410 & .75 & 1,410 & 60.8 \\
\hline \multirow[t]{5}{*}{ BSD-2 } & - & - & - & - & ${ }^{1} .82$ & 1,550 & e83.6 \\
\hline & 940 & 285 & 1,700 & 1,860 & .81 & 1,860 & 113 \\
\hline & 890 & 264 & 1,750 & 1,790 & .76 & 1,790 & 39.1 \\
\hline & 1,200 & 284 & 2,110 & 2,300 & .87 & 2,300 & 57.1 \\
\hline & - & - & - & - & ${ }^{1} .82$ & 1,920 & 88.0 \\
\hline
\end{tabular}


Table 2. Instantaneous discharge and properties of water samples collected from water-quality monitoring sites near Manila, Utah -Continued

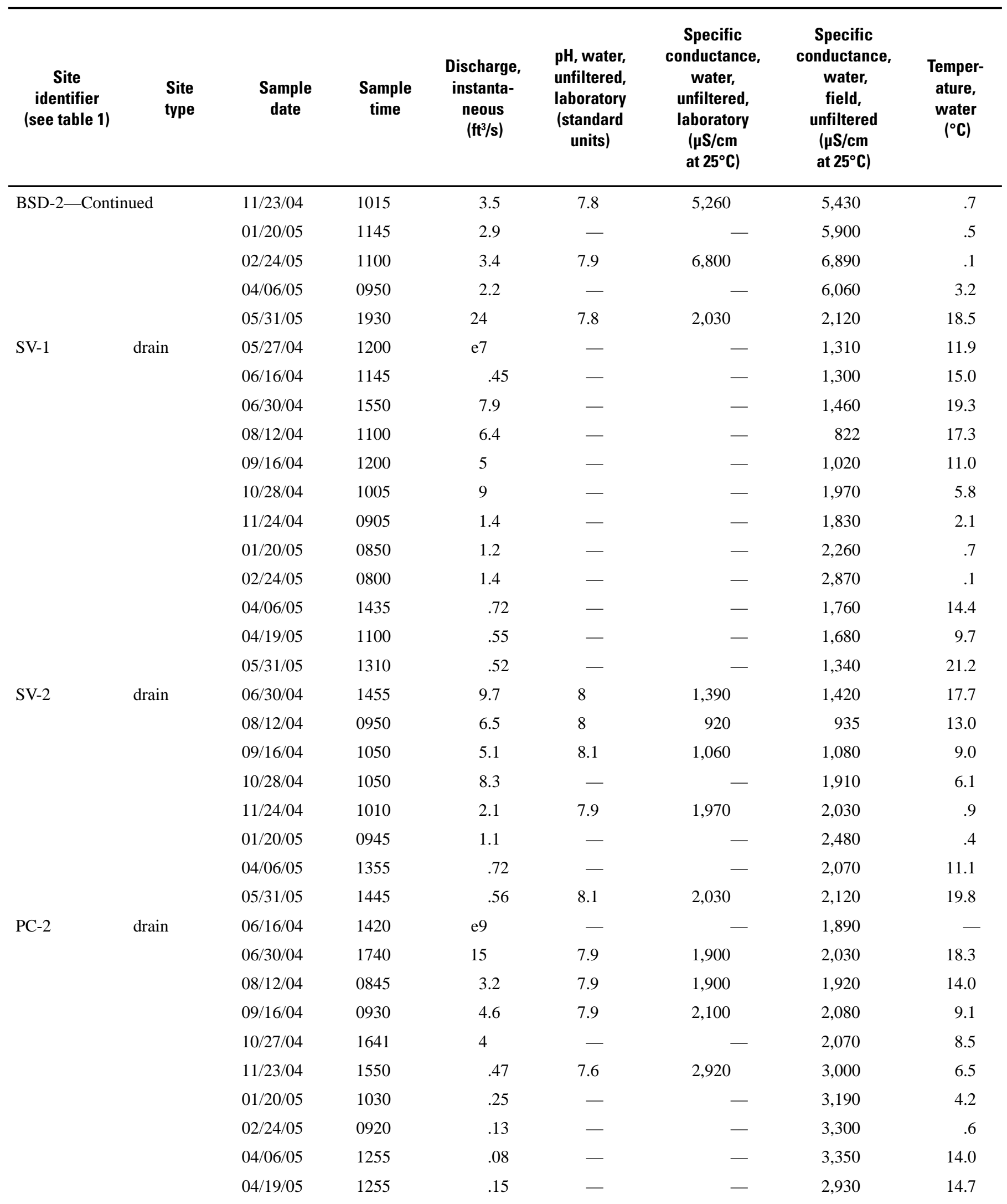


Table 2. Instantaneous discharge and properties of water samples collected from water-quality monitoring sites near Manila, Utah-Continued

\begin{tabular}{|c|c|c|c|c|c|c|c|}
\hline $\begin{array}{c}\text { Site } \\
\text { identifier } \\
\text { (see table 1) }\end{array}$ & $\begin{array}{c}\text { Hardness, } \\
\text { water } \\
\text { (mg/L as } \\
\mathrm{CaCO}_{3} \text { ) }\end{array}$ & $\begin{array}{c}\text { Alkalinity, } \\
\text { water, filtered, } \\
\text { incremental } \\
\text { titration, lab } \\
(\mathrm{mg} / \mathrm{L})\end{array}$ & $\begin{array}{c}\text { Dissolved- } \\
\text { solids } \\
\text { concentration, } \\
\text { sum of } \\
\text { constituents, } \\
\text { water, } \\
\text { filtered } \\
\text { (mg/L) } \\
\end{array}$ & $\begin{array}{l}\text { Dissolved- } \\
\text { solids } \\
\text { concentration, } \\
\text { ROE, water, } \\
\text { filtered } \\
\text { (mg/L) }\end{array}$ & $\begin{array}{c}\mathrm{ROE} / \\
\text { Specific- } \\
\text { conductance } \\
\text { ratio }\end{array}$ & $\begin{array}{c}\text { Dissolved- } \\
\text { solids } \\
\text { concentration } \\
\text { from ROE/ } \\
\text { Specific- } \\
\text { conductance } \\
\text { ratio } \\
\text { (mg/L) } \\
\end{array}$ & $\begin{array}{c}\text { Dissolved- } \\
\text { solids } \\
\text { load } \\
\text { (tons } \\
\text { per day) }\end{array}$ \\
\hline \multirow[t]{5}{*}{ BSD-2 } & 2,100 & 384 & 4,560 & 4,850 & .89 & 4,850 & 45.8 \\
\hline & - & - & - & - & ${ }^{1} .82$ & 4,840 & 37.8 \\
\hline & 2,200 & 403 & 5,740 & 5,940 & .86 & 5,940 & 54.5 \\
\hline & - & - & - & - & ${ }^{1} .82$ & 4,970 & 29.5 \\
\hline & 700 & 215 & 1,450 & 1,580 & .75 & 1,580 & 102 \\
\hline \multirow[t]{12}{*}{ SV-1 } & - & - & - & & ${ }^{1} .69$ & 904 & e17.1 \\
\hline & - & - & - & 882 & .68 & 882 & 1.07 \\
\hline & - & - & - & 1,040 & .71 & 1,040 & 22.2 \\
\hline & - & - & - & 555 & .68 & 555 & 9.58 \\
\hline & - & - & - & 700 & .69 & 700 & 9.44 \\
\hline & - & - & - & - & $\begin{array}{l}1.69 \\
\end{array}$ & 1,360 & 33.0 \\
\hline & - & 173 & - & 1,310 & .72 & 1,310 & 4.95 \\
\hline & - & - & - & - & $\begin{array}{l}{ }^{1} .69 \\
\end{array}$ & 1,560 & 5.05 \\
\hline & - & - & - & - & $\begin{array}{l}1 \\
{ }^{1} .69\end{array}$ & 1,980 & 7.48 \\
\hline & - & - & - & - & $\begin{array}{l}1.69 \\
\end{array}$ & 1,210 & 2.36 \\
\hline & - & - & - & - & $\begin{array}{l}1.69 \\
\end{array}$ & 1,160 & 1.72 \\
\hline & - & - & - & - & $\begin{array}{l}{ }^{1} .69 \\
\end{array}$ & 925 & 1.30 \\
\hline \multirow[t]{8}{*}{ SV-2 } & 580 & 341 & 999 & 1,020 & .72 & 1,020 & 26.7 \\
\hline & 360 & 352 & 592 & 639 & .68 & 639 & 11.2 \\
\hline & 410 & 296 & 716 & 751 & .70 & 751 & 10.3 \\
\hline & - & - & - & - & ${ }^{1} .70$ & 1,340 & 29.9 \\
\hline & 730 & - & 1,430 & 1,460 & .72 & 1,460 & 8.27 \\
\hline & - & - & - & - & ${ }^{1} .70$ & 1,740 & 5.15 \\
\hline & - & - & - & - & ${ }^{1} .70$ & 1,450 & 2.81 \\
\hline & 640 & - & 1,420 & 1,490 & .70 & 1,490 & 2.25 \\
\hline \multirow[t]{10}{*}{ PC-2 } & - & - & - & - & ${ }^{1} .86$ & 1,630 & e39.5 \\
\hline & 930 & 257 & 1,550 & 1,700 & .84 & 1,700 & 68.8 \\
\hline & 880 & 240 & 1,470 & 1,640 & .85 & 1,640 & 14.2 \\
\hline & 1,100 & 254 & 1,680 & 1,830 & .88 & 1,830 & 22.7 \\
\hline & - & - & - & - & ${ }^{1} .86$ & 1,780 & 19.2 \\
\hline & 1,700 & 303 & 2,620 & 2,800 & .93 & 2,800 & 3.55 \\
\hline & - & - & - & - & ${ }^{1} .86$ & 2,740 & 1.85 \\
\hline & - & - & - & - & ${ }^{1} .86$ & 2,840 & 1.00 \\
\hline & - & - & - & - & ${ }^{1} .86$ & 2,880 & .62 \\
\hline & - & - & - & - & ${ }^{1} .86$ & 2,520 & 1.02 \\
\hline
\end{tabular}


Table 2. Instantaneous discharge and properties of water samples collected from water-quality monitoring sites near Manila, Utah -Continued

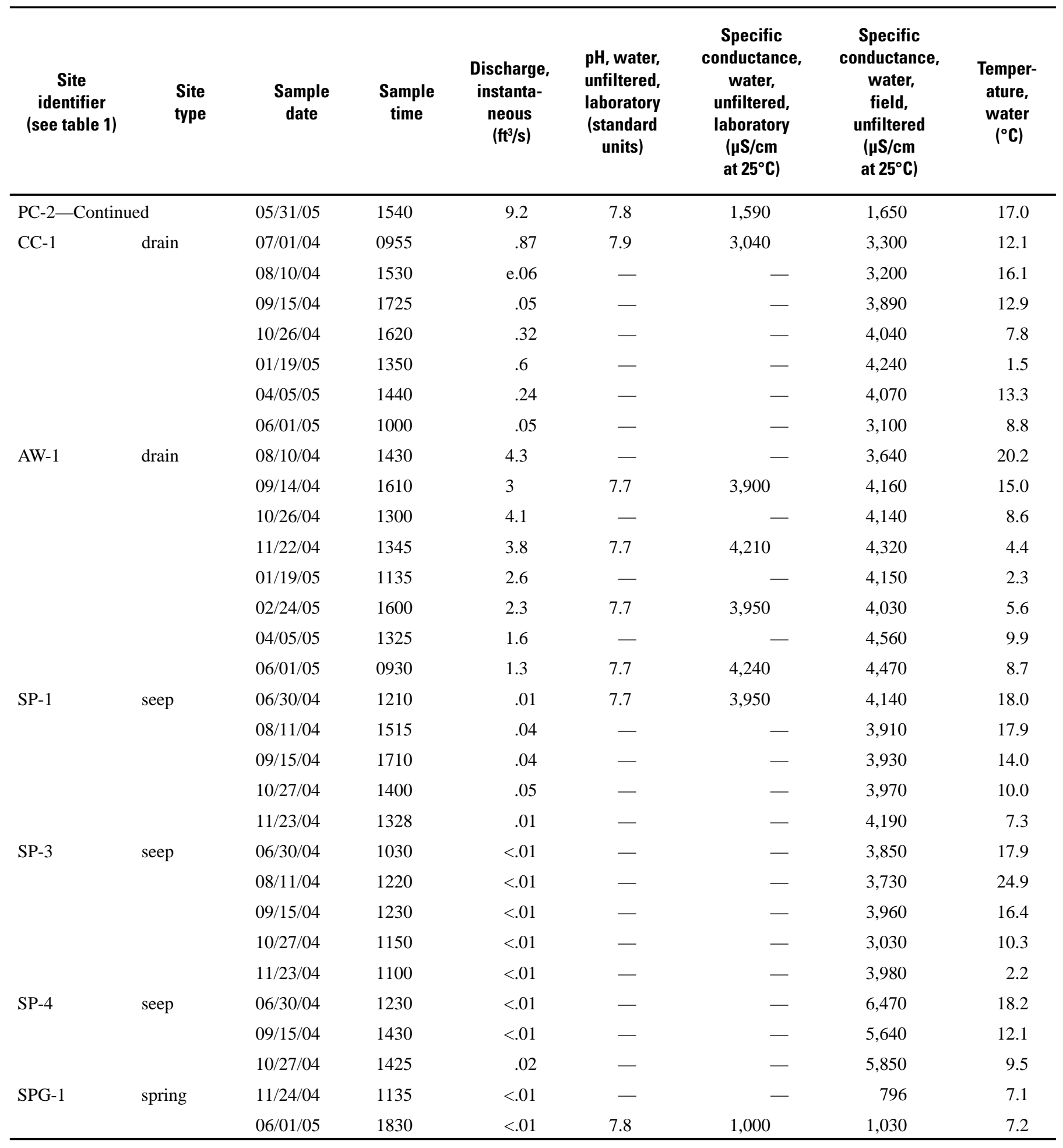

\footnotetext{
${ }^{1}$ Ratio is either the average of calculated values for that site, or if there are no calculated values for the site, the average of calculated values for the site type.
} 
Table 2. Instantaneous discharge and properties of water samples collected from water-quality monitoring sites near Manila, Utah-Continued

\begin{tabular}{|c|c|c|c|c|c|c|c|}
\hline $\begin{array}{c}\text { Site } \\
\text { identifier } \\
\text { (see table 1) }\end{array}$ & $\begin{array}{l}\text { Hardness, } \\
\text { water } \\
\text { (mg/L as } \\
\mathrm{CaCO}_{3} \text { ) }\end{array}$ & $\begin{array}{c}\text { Alkalinity, } \\
\text { water, filtered, } \\
\text { incremental } \\
\text { titration, lab } \\
\text { (mg/L) }\end{array}$ & $\begin{array}{c}\text { Dissolved- } \\
\text { solids } \\
\text { concentration, } \\
\text { sum of } \\
\text { constituents, } \\
\text { water, } \\
\text { filtered } \\
\text { (mg/L) } \\
\end{array}$ & $\begin{array}{l}\text { Dissolved- } \\
\text { solids } \\
\text { concentration, } \\
\text { ROE, water, } \\
\text { filtered } \\
\text { (mg/L) }\end{array}$ & $\begin{array}{c}\text { ROE/ } \\
\text { Specific- } \\
\text { conductance } \\
\text { ratio }\end{array}$ & $\begin{array}{c}\text { Dissolved- } \\
\text { solids } \\
\text { concentration } \\
\text { from ROE/ } \\
\text { Specific- } \\
\text { conductance } \\
\text { ratio } \\
\text { (mg/L) } \\
\end{array}$ & $\begin{array}{l}\text { Dissolved- } \\
\text { solids } \\
\text { load } \\
\text { (tons } \\
\text { per day) }\end{array}$ \\
\hline PC-2 & 740 & 191 & 1,200 & 1,310 & .79 & 1,310 & 32.5 \\
\hline \multirow[t]{7}{*}{ CC-1 } & 1,900 & 282 & 2,800 & 3,120 & .95 & 3,120 & 7.32 \\
\hline & - & - & - & - & .96 & 3,070 & e.50 \\
\hline & - & - & - & - & ${ }^{1} .96$ & 3,730 & .50 \\
\hline & - & - & - & - & ${ }^{1} .96$ & 3,880 & 3.35 \\
\hline & - & - & - & - & ${ }^{1} .96$ & 4,070 & 6.59 \\
\hline & - & - & - & - & ${ }^{1} .96$ & 3,910 & 2.53 \\
\hline & - & - & - & - & ${ }^{1} .96$ & 2,980 & .40 \\
\hline \multirow[t]{8}{*}{ AW-1 } & - & - & - & 3,580 & .98 & 3,580 & 41.5 \\
\hline & 2,500 & 286 & 3,720 & 4,080 & .98 & 4,080 & 33.0 \\
\hline & - & - & - & - & ${ }^{1} 1.00$ & 4,140 & 45.8 \\
\hline & 2,800 & - & - & 4,450 & 1.03 & 4,450 & 45.6 \\
\hline & - & - & - & - & ${ }^{1} 1.00$ & 4,150 & 29.1 \\
\hline & 2,700 & 312 & 3,790 & 4,080 & 1.01 & 4,080 & 25.3 \\
\hline & - & - & - & - & ${ }^{1} 1.00$ & 4,560 & 19.7 \\
\hline & 2,700 & 352 & 3,960 & 4,340 & .97 & 4,340 & 15.2 \\
\hline \multirow[t]{5}{*}{ SP-1 } & 1,800 & 357 & 3,510 & 3,650 & .88 & 3,650 & .10 \\
\hline & - & - & - & 3,710 & .95 & 3,710 & .40 \\
\hline & - & - & - & 3,690 & .94 & 3,690 & .40 \\
\hline & - & - & - & - & ${ }^{1} .92$ & 3,650 & .49 \\
\hline & - & - & - & - & ${ }^{1} .92$ & 3,850 & .10 \\
\hline \multirow[t]{5}{*}{ SP-3 } & - & - & - & - & ${ }^{1} .92$ & 3,540 & $<.10$ \\
\hline & - & - & - & - & ${ }^{1} .92$ & 3,430 & $<.09$ \\
\hline & - & - & - & - & ${ }^{1} .92$ & 3,640 & $<.10$ \\
\hline & - & - & - & - & ${ }^{1} .92$ & 2,790 & $<.08$ \\
\hline & - & - & - & - & ${ }^{1} .92$ & 3,660 & $<.10$ \\
\hline \multirow[t]{3}{*}{ SP-4 } & - & - & - & - & ${ }^{1} .92$ & 5,950 & $<.16$ \\
\hline & - & - & - & - & ${ }^{1} .92$ & 5,190 & $<.14$ \\
\hline & - & - & - & - & ${ }^{1} .92$ & 5,380 & .29 \\
\hline \multirow[t]{2}{*}{ SPG-1 } & - & - & - & 638 & .80 & 638 & $<.02$ \\
\hline & 500 & 314 & 636 & 671 & .65 & 671 & $<.02$ \\
\hline
\end{tabular}


Table 3. Concentration of major ions in water samples collected from water-quality monitoring sites near Manila, Utah

[mg/L, milligrams per liter; <, less than]

\begin{tabular}{|c|c|c|c|c|c|c|}
\hline $\begin{array}{c}\text { Site } \\
\text { identifier } \\
\text { (see table 1) }\end{array}$ & $\begin{array}{l}\text { Site } \\
\text { type }\end{array}$ & Sample date & $\begin{array}{c}\text { Sample } \\
\text { time }\end{array}$ & $\begin{array}{c}\text { Calcium, } \\
\text { water, } \\
\text { filtered } \\
(\mathrm{mg} / \mathrm{L})\end{array}$ & $\begin{array}{c}\text { Magnesium, } \\
\text { water, } \\
\text { filtered } \\
\text { (mg/L) }\end{array}$ & $\begin{array}{c}\text { Potassium, } \\
\text { water, } \\
\text { filtered } \\
\text { (mg/L) }\end{array}$ \\
\hline HFK-3 & stream & 09/14/04 & 1840 & 214 & 96.7 & 12.0 \\
\hline \multirow[t]{2}{*}{ SCC-1 } & canal & 07/01/04 & 1225 & 7.6 & 1.6 & .6 \\
\hline & & 08/10/04 & 1125 & 7.6 & 1.6 & .5 \\
\hline \multirow[t]{3}{*}{ PC-1 } & canal & 06/29/04 & 1400 & 141 & 59.4 & 8.6 \\
\hline & & $09 / 14 / 04$ & 1430 & 161 & 90.0 & 12.3 \\
\hline & & 06/01/05 & 0840 & 46.5 & 15.8 & 3.6 \\
\hline DRN-1 & drain & 06/29/04 & 1635 & 271 & 125 & 13.7 \\
\hline \multirow[t]{2}{*}{ DRN-1a } & drain & $11 / 23 / 04$ & 1440 & 504 & 235 & 13.0 \\
\hline & & 06/01/05 & 1220 & 320 & 228 & 13.8 \\
\hline \multirow[t]{3}{*}{ DRN-2 } & drain & 06/29/04 & 1740 & 232 & 106 & 14.9 \\
\hline & & 09/15/04 & 1700 & 360 & 162 & 14.5 \\
\hline & & 06/01/05 & 1350 & 240 & 143 & 7.4 \\
\hline DRN-4 & drain & 06/01/05 & 1530 & 111 & 49.1 & 6.6 \\
\hline BSD-1 & drain & $06 / 16 / 04$ & 0940 & 150 & 77.8 & 6.5 \\
\hline \multirow[t]{6}{*}{ BSD-2 } & drain & 06/30/04 & 0855 & 199 & 107 & 9.3 \\
\hline & & 08/11/04 & 1035 & 190 & 102 & 9.7 \\
\hline & & 09/15/04 & 1105 & 244 & 131 & 11.8 \\
\hline & & $11 / 23 / 04$ & 1015 & 407 & 253 & 16.5 \\
\hline & & $02 / 24 / 05$ & 1100 & 372 & 315 & 19.8 \\
\hline & & 05/31/05 & 1930 & 136 & 87.6 & 8.6 \\
\hline \multirow[t]{5}{*}{ SV-2 } & drain & 06/30/04 & 1455 & 122 & 67.2 & 11.2 \\
\hline & & 08/12/04 & 0950 & 69.9 & 44.6 & 8.5 \\
\hline & & 09/16/04 & 1050 & 80.9 & 51.0 & 5.4 \\
\hline & & $11 / 24 / 04$ & 1010 & 128 & 99.9 & 7.5 \\
\hline & & $05 / 31 / 05$ & 1445 & 98.4 & 95.5 & 9.5 \\
\hline \multirow[t]{5}{*}{ PC-2 } & drain & 06/30/04 & 1740 & 230 & 86.9 & 10.3 \\
\hline & & 08/12/04 & 0845 & 222 & 79.6 & 8.5 \\
\hline & & 09/16/04 & 0930 & 268 & 97.7 & 10.1 \\
\hline & & $11 / 23 / 04$ & 1550 & 520 & 108 & 10.5 \\
\hline & & 05/31/05 & 1540 & 191 & 63.2 & 7.5 \\
\hline CC-1 & drain & 07/01/04 & 0955 & 373 & 233 & 26.6 \\
\hline \multirow[t]{4}{*}{ AW-1 } & drain & 09/14/04 & 1610 & 488 & 322 & 26.5 \\
\hline & & $11 / 22 / 04$ & 1345 & 531 & 350 & 28.0 \\
\hline & & $02 / 24 / 05$ & 1600 & 510 & 337 & 23.7 \\
\hline & & 06/01/05 & 0930 & 473 & 372 & 25.1 \\
\hline SP-1 & seep & $06 / 30 / 04$ & 1210 & 461 & 164 & 12.6 \\
\hline SPG-1 & spring & 06/01/05 & 1830 & 83.2 & 70.3 & 4.2 \\
\hline
\end{tabular}


Table 3. Concentration of major ions in water samples collected from water-quality monitoring sites near Manila, Utah—Continued

\begin{tabular}{|c|c|c|c|c|c|}
\hline $\begin{array}{c}\text { Site } \\
\text { identifier } \\
\text { (see table 1) }\end{array}$ & $\begin{array}{c}\text { Sodium, } \\
\text { water, } \\
\text { filtered } \\
(\mathrm{mg} / \mathrm{L})\end{array}$ & $\begin{array}{c}\text { Chloride, } \\
\text { water, } \\
\text { filtered } \\
\text { (mg/L) }\end{array}$ & $\begin{array}{c}\text { Fluoride, } \\
\text { water, } \\
\text { filtered } \\
\text { (mg/L) }\end{array}$ & $\begin{array}{c}\text { Silica, } \\
\text { water, } \\
\text { filtered } \\
(\mathrm{mg} / \mathrm{L})\end{array}$ & $\begin{array}{r}\text { Sulfate, } \\
\text { water, } \\
\text { filtered } \\
(\mathrm{mg} / \mathrm{L})\end{array}$ \\
\hline HFK-3 & 78.8 & 22.3 & 0.8 & 24.7 & 767 \\
\hline \multirow[t]{2}{*}{ SCC-1 } & 1.3 & .6 & $<.2$ & 3.9 & 6.6 \\
\hline & 1.1 & .5 & $<.2$ & 3.7 & 6.7 \\
\hline \multirow[t]{3}{*}{ PC-1 } & 41.0 & 11.8 & .5 & 22.8 & 364 \\
\hline & 60.6 & 16.6 & .6 & 24.2 & 635 \\
\hline & 10.1 & 3.4 & .2 & 14.7 & 67 \\
\hline DRN-1 & 173 & 44.2 & .7 & 34.8 & 1,030 \\
\hline \multirow[t]{2}{*}{ DRN-1a } & 568 & 165 & 1.1 & 27.6 & 2,590 \\
\hline & 477 & 140 & 1.2 & 22.3 & 2,070 \\
\hline \multirow[t]{3}{*}{ DRN-2 } & 163 & 51.8 & .8 & 36.1 & 857 \\
\hline & 288 & 82.3 & 1.2 & 23.0 & 1,610 \\
\hline & 280 & 105 & 1.0 & 20.7 & 1,340 \\
\hline DRN-4 & 90.0 & 28.8 & .6 & 19.9 & 413 \\
\hline BSD-1 & 197 & 77.6 & .5 & 13.3 & 686 \\
\hline \multirow[t]{6}{*}{ BSD-2 } & 224 & 82.5 & .6 & 18.7 & 894 \\
\hline & 210 & 87.0 & .8 & 18.7 & 972 \\
\hline & 235 & 90.1 & .8 & 20.6 & 1,200 \\
\hline & 751 & 311 & 1.2 & 17.9 & 2,570 \\
\hline & 1,100 & 475 & 1.2 & 15.7 & 3,200 \\
\hline & 232 & 101 & .5 & 22.6 & 737 \\
\hline \multirow[t]{5}{*}{ SV-2 } & 126 & 27.5 & .7 & 24.2 & 416 \\
\hline & 74.7 & 20.0 & .7 & 21.0 & 141 \\
\hline & 92.5 & 23.1 & .7 & 13.0 & 272 \\
\hline & 239 & 55.4 & 1.0 & 19.4 & 622 \\
\hline & 256 & 56.5 & 1.0 & 16.1 & 669 \\
\hline \multirow[t]{5}{*}{ PC-2 } & 145 & 46.7 & .9 & 19.4 & 855 \\
\hline & 116 & 38.7 & .9 & 15.6 & 846 \\
\hline & 122 & 37.7 & 1.0 & 18.6 & 974 \\
\hline & 182 & 61.0 & 1.6 & 18.2 & 1,540 \\
\hline & 118 & 40.7 & .7 & 16.5 & 645 \\
\hline CC-1 & 163 & 37.5 & 1.6 & 31.6 & 1,770 \\
\hline \multirow[t]{4}{*}{ AW-1 } & 201 & 43.1 & 1.9 & 29.3 & 2,440 \\
\hline & 252 & 53.8 & 1.9 & 33.2 & 2,640 \\
\hline & 241 & 46.0 & 1.8 & 27.8 & 2,410 \\
\hline & 245 & 48.7 & 1.9 & 30.2 & 2,550 \\
\hline SP-1 & 462 & 135 & 1.2 & 19.0 & 2,040 \\
\hline SPG-1 & 46.0 & 26.3 & .4 & 12.9 & 204 \\
\hline
\end{tabular}




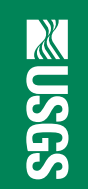

事

ㅇㅇㅇ몽

!

울

오

뭉.

잃

c

के 